\title{
Peripheral signalling involved in energy homeostasis control
}

\author{
Andoni Lancha ${ }^{1,2}$, Gema Frühbeck ${ }^{1,2,3}$ and Javier Gómez-Ambrosi ${ }^{1,2 *}$ \\ ${ }^{1}$ Metabolic Research Laboratory, Clinica Universidad de Navarra, Pamplona, Spain \\ ${ }^{2}$ CIBER Fisiopatología de la Obesidad y Nutrición (CIBERobn), ISCIII, Spain \\ ${ }^{3}$ Department of Endocrinology and Nutrition, Clinica Universidad de Navarra, Pamplona, Spain
}

(Submitted 23 December 2011 - Final revision received 21 May 2012 - Accepted 22 May 2012)

\section{Abstract}

The alarming prevalence of obesity has led to a better understanding of the molecular mechanisms controlling energy homeostasis. Regulation of energy intake and expenditure is more complex than previously thought, being influenced by signals from many peripheral tissues. In this sense, a wide variety of peripheral signals derived from different organs contributes to the regulation of body weight and energy expenditure. Besides the well-known role of insulin and adipokines, such as leptin and adiponectin, in the regulation of energy homeostasis, signals from other tissues not previously thought to play a role in body weight regulation have emerged in recent years. The role of fibroblast growth factor 21 (FGF21), insulin-like growth factor 1 (IGF-I), and sex hormone-binding globulin (SHBG) produced by the liver in the regulation of body weight and insulin sensitivity has been recently described. Moreover, molecules expressed by skeletal muscle such as myostatin have also been involved in adipose tissue regulation. Better known is the involvement of ghrelin, cholecystokinin, glucagon-like peptide 1 (GLP-1) and PYY $3-$ 36, produced by the gut, in energy homeostasis. Even the kidney, through the production of renin, appears to regulate body weight, with mice lacking this hormone exhibiting resistance to diet-induced obesity. In addition, the skeleton has recently emerged as an endocrine organ, with effects on body weight control and glucose homeostasis through the actions of bone-derived factors such as osteocalcin and osteopontin. The comprehension of these signals will help in a better understanding of the aetiopathology of obesity, contributing to the potential development of new therapeutic targets aimed at tackling excess body fat accumulation.

Key words: Peripheral signalling: Energy homeostasis control: Obesity: Adipokines: Cytokines: Hormones

\section{Introduction}

The obesity epidemic poses one of the most serious public health challenges. The prevalence of obesity has increased three-fold over the past three to four decades ${ }^{(1)}$. More than half of all adults in Europe and the USA are overweight. Of these, one-third is already obese and figures are increasing ${ }^{(2)}$. Obesity is a serious medical problem because it increases the risk of type 2 diabetes mellitus (T2DM), CVD, fatty liver, sleep-breathing disorders, and certain forms of cancer, among others ${ }^{(3-8)}$. Moreover, obesity adversely affects the quality of life and shortens life expectancy ${ }^{(9,10)}$.

The alarming prevalence of obesity has led to a greater understanding of the molecular mechanisms that regulate energy homeostasis and body weight control ${ }^{(11)}$. Energy balance regulation is an extremely complex process that integrates multiple interacting homeostatic and behavioural pathways. In recent years, awareness has been raised regarding the increasing number of neuropeptides involved in the hypothalamic integration of peripheral signals derived mainly from the pancreas and adipose tissue ${ }^{(12)}$. The existing evidence collected over recent years through targeted expression or knockout of specific genes involved in the pathways controlling energy intake, energy expenditure, adiposity or fat distribution has contributed to disentangling the mechanisms controlling energy homeostasis ${ }^{(13)}$. Thus, regulation of energy intake and expenditure is more complex than previously thought, being influenced by signals from many other peripheral tissues ${ }^{(14-18)}$. In this sense, a wide variety of peripheral signals derived from different organs contributes to the regulation of body weight and energy expenditure. In addition to the well-known role of insulin (from the pancreas) and adipokines, such as leptin

\footnotetext{
Abbreviations: AgRP, Agouti-related peptide; AMPK, AMP-activated protein kinase; Ang, angiotensin; ANP, atrial natriuretic peptide; ASP, acylationstimulating protein; BAT, brown adipose tissue; BNP, brain natriuretic peptide; CCK, cholecystokinin; CCK1R, cholecystokinin-1 receptor; cGMP, cyclic guanosine monophosphate; CNP, c-type natriuretic peptide; ER, oestrogen receptor; FGF, fibroblast growth factor; GIP, glucose-dependent insulinotropic polypeptide; GLP, glucagon-like peptide; GUCY, guanylyl cyclase; IGF, insulin-like growth factor; IGFBP, insulin-like growth factorbinding protein; NPY, neuropeptide Y; POMC, pro-opiomelanocortin; PP, pancreatic polypeptide; PYY, peptide YY; SHBG, sex hormone-binding globulin; T2DM, type 2 diabetes mellitus; T3, triiodothyronine; THR, thyroid hormone receptor; vaspin, visceral adipose tissue-derived serpin.
} 
and adiponectin (from adipose tissue), in the regulation of energy homeostasis, signals from other tissues not previously thought to be involved in body weight regulation have emerged in recent years. The role of emerging proteins produced by the liver such as fibroblast growth factor (FGF) 21 in the regulation of body weight and insulin sensitivity has been described recently. Moreover, molecules expressed by skeletal muscle such as myostatin have also been involved in adipose tissue regulation. Better known is the involvement of ghrelin, cholecystokinin (CCK), glucagon-like peptide (GLP)-1 and peptide YY (PYY) $3-36$, produced by the gut, in energy homeostasis ${ }^{(19)}$. Even the kidney, through the production of renin, appears to regulate body weight, because mice lacking this hormone exhibit resistance to diet-induced obesity ${ }^{(14)}$. In addition, the skeleton has recently emerged as an endocrine organ, with effects on body weight control and glucose homeostasis through the actions of bone-derived factors such as osteocalcin and osteopontin $^{(15)}$. The cross-talk between adipose tissue and the skeleton constitutes a homeostatic feedback system, with adipokines and molecules secreted by osteoblasts and osteoclasts representing the links of an active bone-adipose tissue axis. The present review summarises the current state of knowledge of the peripherals signals involved in the regulation of energy intake and expenditure.

\section{Signals from adipose tissue}

The concept that circulating signals secreted in proportion to body fat stores regulate energy intake and expenditure in a coordinated manner to regulate body weight was proposed more than 50 years ago ${ }^{(20)}$. According to this model, changes in energy balance sufficient to alter body fat stores were signalled via one or more circulating factors acting in the hypothalamus for triggering compensatory changes in order to match energy intake to energy expenditure ${ }^{(21)}$. This was formulated as the 'lipostatic theory', presuming that as adipose tissue mass expands, a factor that operates as a sensing hormone or 'lipostat' in a negative feedback control from adipose tissue to hypothalamic receptors informs the brain about the size of the body fat stores, thereby allowing feeding behaviour and energy expenditure to be coupled to the nutritional state of the organism. Current knowledge has fostered the idea of a far more complex system than initially thought from the formulation of the lipostatic theory, involving the integration of a multitude of factors ${ }^{(21)}$. This pleiotropic nature relies on the ability of adipocytes to secrete a large number of hormones, growth factors, enzymes, cytokines and matrix proteins, collectively termed as adipokines, which warrant an appropriate feedback response to changes in adipose tissue mass ${ }^{(22-25)}$.

\section{Leptin}

Leptin is an adipokine mainly produced by adipocytes in proportion to fat stores ${ }^{(26)}$. It was originally thought to be only involved in energy intake inhibition and body weight regulation acting at its hypothalamic receptors. This inhibition of appetite takes place mainly through the inhibition of neuropeptide Y (NPY)- and Agouti-related peptide (AgRP)-expressing neurons and the stimulation of pro-opiomelanocortin (POMC)-expressing neurons in the hypothalamic arcuate nucleus ${ }^{(27)}$. However, a significant number of leptin receptor-expressing neurons lie outside the hypothalamic arcuate nucleus, suggesting that other brain regions known to modulate energy balance are involved in leptin's anorectic effect ${ }^{(28)}$. Although food intake regulation is a major role of leptin, its receptor is expressed in almost all tissues ${ }^{(29-31)}$, underlining a high functional pleiotropism involving energy homeostasis, glucose metabolism, reproduction, angiogenesis, immunity, gastrointestinal function, wound healing, bone remodelling and cardiovascular function ${ }^{(32-38)}$. Plasma leptin concentrations are increased in obese patients, being strongly correlated with BMI and the percentage of body fat, as well as with leptin mRNA expression in adipose tissue ${ }^{(23,39,40)}$. The failure of high leptin concentrations to suppress feeding and mediate weight loss in common obesity defines what has been termed leptin resistance ${ }^{(36)}$.

Leptin-deficient $o b / o b$ mice and leptin receptor-deficient $d b / d b$ mutants show early-onset obesity, diabetes and reduced energy expenditure ${ }^{(41)}$. Leptin administration induces a dramatic loss of adipose mass in rodents ${ }^{(42,43)}$. This effect is not only mediated by a reduction in energy intake, but also by a direct effect on adipose tissue ${ }^{(43)}$. In this sense, leptin inhibits lipogenesis and stimulates lipolysis in adipocytes through a direct effect ${ }^{(44,45)}$ or a centrally mediated action ${ }^{(46)}$ without the release of NEFA, which are intracellularly oxidised ${ }^{(47)}$. Furthermore, leptin replacement in leptin-deficient mice increases energy expenditure $^{(42,48)}$. A few leptin-deficient patients who also exhibit severe early-onset obesity and hormonal alterations have been identified $^{(49,50)}$. Surprisingly, BMR and total energy expenditure were similar to those of age-, sex- and weight-matched controls ${ }^{(51)}$. Leptin replacement in humans reduces body weight mainly at the expense of the fat compartment and reverses metabolic and hormonal alterations $^{(51-54)}$. Interestingly, the weight loss-associated decrease in energy expenditure that takes places after prolonged negative energy balance was less pronounced in leptin-treated patients than in obese leptin-replete controls following a weight-loss programme ${ }^{(51,52,55,56)}$. Therefore, leptin prevents the reduction in metabolic rate that is associated with weight loss ${ }^{(52,55,56)}$.

\section{Adiponectin}

The adipokine adiponectin is highly expressed in adipose tissue and its circulating concentrations are considerably high, accounting for approximately $0.01 \%$ of total serum protein $^{(57-59)}$. Adiponectin exerts a wide variety of physiological roles through the binding of at least three different 
receptors called AdipoR1, AdipoR2 and T-cadherin ${ }^{(60,61)}$. Serum concentrations of adiponectin are decreased in obese subjects ${ }^{(62,63)}$ and increase with weight $\operatorname{loss}^{(64)}$. Hypoadiponectinaemia is associated with insulin resistance and patients with T2DM are reported to have decreased concentrations of adiponectin ${ }^{(63,65,66)}$. Patients with CVD also exhibit lower adiponectin concentrations ${ }^{(67)}$. In addition, administration of adiponectin induces glucose-lowering effects and improves insulin sensitivity in rodent models of obesity-associated diabetes ${ }^{(68,69)}$. Moreover, adiponectin also exhibits anti-atherosclerotic properties $^{(70)}$. Adiponectin-deficient mice as well as mice lacking adiponectin receptors confirm the protective effects of this adipokine in the development of insulin resistance and atherosclerosis ${ }^{(71-73)}$.

Although the insulin-sensitising effects of adiponectin are clear, the effects of this adipokine in energy intake and energy expenditure regulation are still a matter of controversy ${ }^{(74)}$. A lack of effect of intracerebroventricularly administered adiponectin on energy intake has been described. At the same time, weight-reducing actions through an increase in energy expenditure in normal mice have been shown ${ }^{(75)}$. These observations are confirmed in the long term after a 4 -week treatment ${ }^{(76)}$. However, other authors have reported that adiponectin increases energy intake through the stimulation of AMP-activated protein kinase (AMPK) in the hypothalamic arcuate nucleus via AdipoR1 with a concomitant decrease in oxygen consumption ${ }^{(77)}$. Adiponectin- or AdipoR1deficient mice show no changes in energy intake under a normal diet ${ }^{(71,73,78)}$ but, when challenged with a high-fat diet, adiponectin knock-out mice show a reduced energy intake accompanied by an increase in oxygen consumption. The absence of lower food consumption in mice lacking adiponectin under a normal diet can be explained by a compensatory increase in the orexigenic pathways in order to avoid excessive weight loss. This reduction in food intake could be detrimental given the increase in energy expenditure observed after adiponectin administration ${ }^{(77)}$.

\section{Resistin}

Resistin is another adipokine which was initially proposed as a link between increased adiposity and $\mathrm{T}_{2} \mathrm{DM}^{(79)}$. Resistin has been reported to be highly expressed in adipose tissue in mice. Under physiological circumstances, resistin appears to oppose insulin action in adipocytes and to impair glucose tolerance and insulin sensitivity in mice. Moreover, insulinstimulated glucose uptake by adipocytes is enhanced by resistin neutralisation and is reduced by resistin treatment ${ }^{(79,80)}$. Different genetic and dietary models of rodent obesity exhibit increased serum concentrations of resis$\operatorname{tin}^{(79,81)}$. Moreover, transgenic overexpression of resistin leads to insulin resistance in mice ${ }^{(82)}$ and rats ${ }^{(83)}$. In this sense, $o b / o b$ mice simultaneously lacking resistin exhibit an improved glucose tolerance and insulin sensitivity ${ }^{(84)}$.
The exact role of resistin in human physiology and whether or not resistin is involved in the development of insulin resistance still need to be completely elucidated $^{(80,85,86)}$. Several groups have described increased concentrations of resistin in obesity ${ }^{(87,88)}$, while others report no existing differences ${ }^{(89-91)}$. However, cross-sectional and prospective epidemiological investigations reveal that human resistin is not significantly involved in the development of insulin resistance ${ }^{(92-94)}$ or the metabolic syndrome ${ }^{(95)}$. Rather than a role in the development of insulin resistance, considerable evidence links resistin to inflammation ${ }^{(81,85,96)}$. In this respect, it has been reported that resistin markedly up-regulates pro-inflammatory cytokines ${ }^{(97,98)}$ and that inflammation up-regulates resistin in human macrophages ${ }^{(99,100)}$. Furthermore, it has been confirmed that resistin is related to markers of inflammation, being a predictive factor of atherosclerosis ${ }^{(101)}$, and that it also influences pro-inflammatory cytokine release from human adipocytes ${ }^{(102)}$. However, the precise physiological role of resistin in the pathogenesis and perpetuation of inflammation and CVD in humans remains unclear ${ }^{(81)}$.

Central administration of resistin induces a short-term decrease in food intake in rats ${ }^{(103-105)}$, mainly associated with a suppression of the normal fasting-induced increase in the orexigenic neuropeptides NPY and AgRP, and a suppression of the decrease in cocaine and amphetamineregulated transcript $\left(\right.$ CART) ${ }^{(106)}$. However, other authors have described an up-regulation of hypothalamic NPY after intracerebroventricular administration of resistin in mice without measuring the potential effect on food intake $^{(107)}$. Furthermore, leptin-deficient $o b / o b$ mice lacking resistin exhibit higher body weight and body adiposity than $o b / o b$ mice with normal resistin levels ${ }^{(84)}$. This observation has been attributed to a lower metabolic rate, uncovering a crucial role of resistin in the regulation of thermogenesis. In addition to its inhibitory effect on adipogenesis $^{(108)}$, the anorexigenic and thermogenic effects of resistin underscore the relevance of this molecule as an interesting regulator of energy homeostasis. It still remains to be elucidated whether resistin acts on the brain or peripheral tissues to control metabolic rate. The complex actions of resistin on energy expenditure and the expression of resistin in several hypothalamic nuclei suggest that resistin may act in an autocrine/paracrine fashion for regulating body weight, deserving further research ${ }^{(109)}$.

\section{Acylation-stimulating protein}

Acylation-stimulating protein (ASP) is an adipokine predominantly produced by fully differentiated adipocytes ${ }^{(110)}$. ASP results from the cleavage of the complement C3 via factor B and adipsin (factor D) interaction producing C3a, which is rapidly desarginated to give ASP (also known as C3adesArg) $)^{(111)}$. ASP increases after a fat-containing meal and stimulates TAG synthesis and storage $^{(23,112)}$. ASP also stimulates translocation of GLUT1 
to the cell surface ${ }^{(113)}$. Differences between adipose tissue depots have been observed, with greater ASP binding and action in subcutaneous compared with omental fat, in females compared with males, and in obese compared with non-obese subjects, suggesting that ASP could be a female lipogenic factor ${ }^{(114)}$. Circulating concentrations of ASP have been reported to be increased in obese and T2DM subjects ${ }^{(111)}$

Mice lacking complement C3 are deficient in ASP. These mice exhibit a striking phenotype, being leaner in spite of having a significantly increased food intake, which is counterbalanced by increased energy expenditure ${ }^{(115,116)}$. Similarly, mice lacking the ASP receptor $\mathrm{C} 5 \mathrm{~L} 2$ showed a phenotype similar to ASP-deficient mice, with delayed postprandial TAG clearance, increased dietary food intake, and increased muscle fatty acid oxidation ${ }^{(117)}$. Furthermore, exogenously administered ASP increases energy storage while ASP antibody neutralisation increases whole body energy utilisation in mice ${ }^{(118)}$. Recently, it has been suggested that injections of ASP in the third ventricle inhibit food intake in rats through an increase in POMC expression ${ }^{(119)}$. Therefore, ASP is pointed out as a potent anabolic hormone that may also be a mediator of energy expenditure. The potential contribution of ASP as a regulator of food intake and energy expenditure in humans remains to be elucidated.

\section{$T N F-\alpha$}

TNF- $\alpha$ is a cytokine involved in the metabolic disturbances of chronic inflammation, playing a major role in pathophysiological processes such as insulin resistance and anorexia $^{(23,120)}$. In addition, TNF- $\alpha$ is a potent negative regulator of adipocyte differentiation ${ }^{(121)}$. Adipose tissue is both a source of and a target for TNF- $\alpha^{(122)}$. It has been suggested that TNF- $\alpha$ is a candidate mediator of insulin resistance in obesity, as it is overexpressed in the adipose tissue of obese rodents and humans ${ }^{(123)}$. This cytokine blocks the action of insulin in adipose tissue and skeletal muscle in vitro and in vivo. In this sense, TNF- $\alpha$-deficient mice exhibit protection from the development of obesityinduced insulin resistance ${ }^{(124)}$.

The anorexigenic and cachexic effects of TNF- $\alpha$ are well known ${ }^{(125,126)}$. This cytokine modulates the expression of neurotransmitters involved in the control of energy homeostasis, favouring anorexia and energy expenditure ${ }^{(127)}$. Brown adipose tissue (BAT) is a particular form of adipose tissue, functionally and morphologically distinct from white adipose tissue, specialised in dissipating energy in the form of heat ${ }^{(128,129)}$. BAT has been suggested to play a role in human energy homeostasis ${ }^{(129,130)}$. Several controversial studies suggest that TNF- $\alpha$ may modulate the thermogenic capacity of $\mathrm{BAT}^{(122)}$. Administration of TNF- $\alpha$ increases BAT thermogenic activity ${ }^{(131)}$. This is consistent with the catabolic role of TNF- $\alpha$. In contrast, other studies suggest that TNF- $\alpha$ decreases the activity of BAT ${ }^{(132)}$. Accordingly, the lack of TNF- $\alpha$ receptor 1 improves the thermoadaptive capacity of obese animals ${ }^{(133)}$. However, information regarding the role of $\mathrm{TNF}-\alpha$ in energy expenditure in humans, beyond its adipose tissue-mobilising effect, is scarce. Disentangling the exact role of TNF- $\alpha$ action in insulin resistance and energy expenditure in humans may provide the basis for the development of novel strategies for treating obesity and the metabolic syndrome.

\section{IL-6}

IL-6 is an inflammatory cytokine with pleiotropic effects on a variety of tissues, including stimulation of acute-phase protein synthesis and regulation of glucose and lipid metabolism $^{(22,23)}$. Adipose tissue produces IL-6, with circulating levels of IL- 6 being proportional to adipose mass and the magnitude of insulin resistance ${ }^{(134,135)}$. Although increased concentrations of IL- 6 have been detected in obese subjects, mice lacking IL-6 develop mature-onset obesity, with the obese phenotype being only partly ameliorated by IL-6 replacement ${ }^{(136)}$. Interestingly, acute IL-6 treatment has been reported to produce an increase in insulin-stimulated glucose disposal in humans in vivo and to induce fatty acid oxidation, glucose transport, and GLUT4 translocation to the plasma membrane in vitro ${ }^{(137)}$. In this sense, IL-6 is considered an autocrine/paracrine regulator of adipocyte function. Its involvement in the development of insulin resistance is still not completely understood ${ }^{(135)}$.

Similarly to TNF- $\alpha$, IL-6 has been shown to trigger catabolic effects ${ }^{(125)}$. In this sense, IL-6 exerts anti-obesity effects centrally by increasing energy expenditure ${ }^{(138)}$, with mice lacking IL-6 exhibiting adult-onset obesity $(136,139)$ through decreased expression of corticotrophin-releasing hormone $(\mathrm{CRH})$ and oxytocin in the hypothalamus. Due to the fact that $\mathrm{CRH}$ is known to stimulate energy expenditure and oxytocin has anorexigenic effects, a reduction in both neuropeptides may be contributing to the obese phenotype of mice lacking IL-6 ${ }^{(140)}$. In humans, exogenous administration of IL-6 increases energy expenditure and activates the hypothalamic-pituitary-adrenal axis, thereby suggesting that $\mathrm{CRH}$ may be mediating this effect, as is observed in mice ${ }^{(141,142)}$. Moreover, a polymorphism in the IL-6 gene has been shown to influence energy expenditure $^{(143)}$. It seems clear that IL-6 regulates energy expenditure; however, its exact involvement in the development of obesity in humans and its potential therapeutic utility remain to be fully elucidated. It should be noted that the treatment of obesity with IL- 6 is not currently under way due to potential major side effects and the lack of knowledge regarding the relative contribution of different target organs to IL-6-induced thermogenesis ${ }^{(144)}$.

\section{Visfatin}

Visfatin, previously identified as nicotinamide phosphoribosyl transferase and colony-enhancing factor of pre-B 
cells, was originally identified as a modulator of $\mathrm{B}$ cell differentiation expressed in lymphocytes, bone marrow, skeletal muscle and liver ${ }^{(145)}$. It was named visfatin because it is highly secreted by visceral fat of both mice and humans and its expression levels in serum increase during the development of obesity ${ }^{(145,146)}$. Visfatin was first reported to have insulin-like activity ${ }^{(146)}$. However, these findings are currently controversial, with the authors having been forced to retract some of their original conclusions ${ }^{(147)}$. Surprisingly, plasma visfatin correlates with measures of obesity but not with visceral fat mass or variables of insulin sensitivity in humans. Furthermore, visfatin mRNA expression does not differ between visceral and subcutaneous adipose tissue ${ }^{(148,149)}$. Nicotinamide phosphoribosyl transferase is thought to play an important role in insulin secretion by pancreatic $\beta$-cells ${ }^{(150)}$ and appears to also be involved in the regulation of the inflammatory response ${ }^{(151)}$.

There is little information regarding the effect of visfatin on energy homeostasis. Central administration of visfatin to Sprague-Dawley rats decreased food intake and locomotor activity, and also increased body temperature ${ }^{(152)}$. These effects resemble those produced by other pro-inflammatory cytokines and they take place via the melanocortin pathway $^{(152)}$. Undoubtedly, more studies are needed in order to fully understand the real implications of visfatin in glucose metabolism and energy homeostasis ${ }^{(93,153)}$.

\section{Visceral adipose tissue-derived serpin}

Visceral adipose tissue-derived serpin (vaspin) is a member of the serine protease inhibitor family. Vaspin is highly expressed in adipocytes of visceral adipose tissue at the same time that obesity and insulin levels peak in Otsuka Long-Evans Tokushima fatty (OLETF) diabetic obese rats. Administration of vaspin to obese insulin-resistant mice improves glucose tolerance and insulin sensitivity. These findings indicate that vaspin exerts an insulin-sensitising effect in states of obesity ${ }^{(154)}$. Human vaspin mRNA expression in adipose tissue is not detectable in lean normoglycaemic individuals, but is induced by increased fat mass and decreased insulin sensitivity, which could represent a compensatory mechanism associated with obesity and $\mathrm{T} 2 \mathrm{DM}^{(155)}$. However, no differences in the levels of vaspin between individuals with normal glucose tolerance and T2DM have been detected ${ }^{(156)}$. The potential involvement of vaspin in glucose homeostasis certainly requires further investigation ${ }^{(157)}$.

Vaspin mRNA in adipose tissue decreases after fasting and its levels are partially recovered after leptin treatment ${ }^{(158)}$. Circulating vaspin concentrations follow a meal-related circadian variation in humans, similar to that seen for ghrelin, suggesting a role for vaspin in the regulation of food intake. Serum vaspin levels exhibit a preprandial rise followed by a rapid decline after meals ${ }^{(159)}$. Both peripheral and central vaspin administration decrease food intake in mice ${ }^{(160)}$. Furthermore, intrahypothalamic vaspin administration reduces food intake in rats, decreasing NPY and increasing POMC mRNA expression ${ }^{(161)}$. Therefore, vaspin exhibits anorexigenic and glucoselowering effects, suggesting its potential use as a therapeutic tool for the treatment of obesity and related diseases. However, the effect of vaspin on energy expenditure needs to be addressed.

\section{Chemerin}

Chemerin, also known as retinoic acid receptor responder 2 , is a secreted chemoattractant protein with an important role in adaptive and innate immunity ${ }^{(25,162)}$. Chemerin has been recently described as an adipokine associated with obesity and the metabolic syndrome ${ }^{(163,164)}$. Furthermore, chemerin contributes to inflammation by stimulating macrophage adhesion to extracellular matrix proteins and by promoting chemotaxis ${ }^{(165)}$. Increased mRNA expression of chemerin has been found in mouse and human adipocytes, while the knockdown of chemerin indicates a major role for this adipokine in regulating adipogenesis and metabolic homeostasis in the adipocyte ${ }^{(164)}$. Increased circulating levels of chemerin have been found in morbidly obese patients, with a significant decrease after bariatric surgery ${ }^{(166,167)}$.

Central administration of chemerin does not modify food intake $24 \mathrm{~h}$ after treatment in rats ${ }^{(161)}$. However, chemerin treatment increases both AgRP and POMC mRNA expression in the hypothalamus. This could lead to a null effect, considering that AgRP is orexigenic and POMC is anorexigenic, but it suggests a role of chemerin in the regulation of neuropeptides involved in food intake regulation $^{(161)}$. The changes in chemerin concentrations after weight loss may merely reflect the reduction in body adiposity, but also a putative role in body weight homeostasis $^{(166,167)}$.

\section{Omentin}

Omentin, also named intelectin or intestinal lactoferrin receptor, is another recently described visceral fat depotspecific adipokine ${ }^{(25,168)}$. It is a secreted protein likely to act as both an endocrine factor to modulate systemic metabolism and an autocrine/paracrine factor to regulate adipocyte biology locally ${ }^{(168,169)}$. Obesity negatively regulates omentin expression and its release into the circulation, with reduced plasma omentin levels having been observed in obese subjects ${ }^{(170)}$. Omentin increases insulin action by enhancing insulin-mediated glucose transport in isolated adipocytes ${ }^{(168,169)}$. Omentin has also been related to inflammation, exerting an anti-inflammatory action and displaying beneficial effects on the metabolic syndrome ${ }^{(171)}$.

Little is known regarding the role of omentin in energy homeostasis. Central administration of omentin produces 
a slight but non-significant increase in food intake in rats $^{(161)}$. In humans, circulating omentin concentrations change oppositely to what takes place in energy balance, thereby rising after prolonged negative energy balance, as is the case after dietary-induced weight loss ${ }^{(172)}$. Further studies are necessary in order to gain more insight regarding the involvement of omentin in the regulation of appetite and energy expenditure.

\section{Angiontensin II}

Murine models of obesity show increased local formation of angiotensin (Ang) II due to elevated secretion of its precursor, angiotensinogen, from adipocytes ${ }^{(23,173,174)}$, with deficiency or overexpression of angiotensinogen affecting body weight regulation ${ }^{(13)}$. Given the close relationship between Ang II and insulin resistance and the fact that the renin-Ang system is inappropriately activated in obesity $^{(175,176)}$, the participation of the adipose tissue-reninAng system in the development of insulin resistance and the metabolic syndrome is conceivable in humans, but has to be evaluated in more detail ${ }^{(173,177)}$.

Mice lacking angiotensinogen or any of its two major receptor subtypes, type 1 (AT1R) and type 2, show protection against the development of obesity without notable changes in food intake ${ }^{(178-180)}$. By contrast, it is clear that these knockout mice exhibit higher energy expenditure, particularly when a high-fat diet is consumed ${ }^{(179,180)}$. Furthermore, mice deficient in Ang-converting enzyme (ACE), which is responsible for the conversion of Ang I to the bioactive peptide Ang II, also have increased energy expenditure, with reduced fat mass and improved glucose clearance ${ }^{(181)}$. Paradoxically, administration of Ang II to rats by means of subcutaneous osmotic minipumps produces a maintained reduction of food intake with a transient decrease in oxygen consumption ${ }^{(182,183)}$. Furthermore, ACE inhibition with captopril reduces food intake and protects against the development of dietinduced obesity and glucose intolerance in rats ${ }^{(184)}$. However, Ang II may exert different effects on metabolism, depending on the tissues of action. In this sense, accumulating evidence suggests that increased Ang II activity locally within the brain promotes negative energy balance $^{(185,186)}$. Taken together, these studies suggest that reduced systemic Ang II signalling protects against dietinduced adipose tissue enlargement by increasing energy expenditure in rodents ${ }^{(173)}$. In humans, although ACE inhibitors and AT1R blockers are widely used as antihypertensive agents and are beginning to be used for promoting insulin sensitivity, there is minimal evidence that these agents significantly affect energy homeostasis ${ }^{(187)}$.

\section{Sex steroids}

Adipose tissue expresses different sex steroid-metabolising enzymes that promote the conversion of oestrogens from androgenic precursors, which are produced by the gonads or adrenal glands, thereby regulating the synthesis and bioavailability of endogenous sex steroids, oestrogens and androgens, through different mechanisms ${ }^{(188-191)}$. In this sense, in men and postmenopausal women, adipose tissue is the main source of oestrogen synthesis, and circulating levels of oestrogens are directly related to BMI. Sex steroid hormones play a critical role in adipose tissue metabolism, distribution and accretion ${ }^{(188,189)}$. In women, menopause-induced oestrogen deficiency and increased androgenicity are associated with increased visceral obesity and with the subsequent cardiometabolic alterations ${ }^{(188)}$. Moreover, hormone replacement therapy with oestradiol treatment for 1 year decreased intra-abdominal fat ${ }^{(192)}$. Ageing in men is associated with a progressive deficit in androgen production and reduced concentrations of testosterone have been related to increased visceral obesity and the metabolic syndrome ${ }^{(193,194)}$. Therefore, treating middle-aged obese men with testosterone reduces abdominal fat ${ }^{(195)}$.

In females, oestrogens regulate energy homeostasis via oestrogen receptor (ER) $\alpha$ and $E R \beta$, by reducing food intake $^{(18,190,196)}$ and $\operatorname{adiposity}^{(197)}$, enhancing energy expenditure $^{(198,199)}$, and improving insulin sensitivity ${ }^{(199)}$. In males, testosterone is converted to oestrogen and controls energy homeostasis via ER and androgen receptors, which share related functions for increasing energy expenditure, reducing fat accumulation ${ }^{(200)}$ and ameliorating glucose homeostasis ${ }^{(191)}$. It has been recently reported that distinct hypothalamic neurons mediate oestrogenic effects on food intake and energy homeostasis. Food intake is regulated by $\mathrm{ER} \alpha$ in POMC neurons while energy expenditure and fat accumulation is controlled by $\mathrm{ER} \alpha$ in steroidogenic factor-1 neurons ${ }^{(201)}$.

\section{Signals from the pancreas}

The major physiological function of the endocrine pancreas is the maintenance of glucose homeostasis. The pancreas senses the concentration of glucose in blood and, through the release of insulin and glucagon, regulates glucose uptake and utilisation by peripheral tissues. However, insulin and glucagon, as well as pancreatic polypeptide (PP) and amylin, also exert a regulatory effect on energy homeostasis ${ }^{(202)}$.

\section{Insulin}

Insulin was the first hormone to be involved in the control of body weight by the central nervous system ${ }^{(202-204)}$. To date, insulin and leptin are the only hormones that fulfil the criteria to be considered an adiposity signal. Both hormones circulate at concentrations proportional to the amount of body fat and enter the central nervous system where leptin and insulin receptors are expressed by neurons involved in energy homeostasis; administration of either molecule into the brain reduces food intake, 
whereas its deficiency does the opposite ${ }^{(27,205)}$. The breeding of mice with brain-specific insulin receptor deficiency, which translates into an increased food intake and diet-sensitive obesity, demonstrated a critical role for brain insulin signalling in the central regulation of energy disposal and fuel metabolism ${ }^{(204)}$. The central effect of insulin on the reduction of food intake is mainly mediated through an inhibition of NPY/AgRP neurons and the stimulation of POMC neurons ${ }^{(27,202)}$. Besides these basic homeostatic circuits, food palatability and reward are thought to be major factors involved in the regulation of food intake elicited by insulin and leptin ${ }^{(206)}$. Although it was initially considered that the effect of insulin was dose dependent, with low doses stimulating thermogenesis and high doses decreasing it ${ }^{(207)}$, further studies have shown the thermogenic effect of insulin ${ }^{(208,209)}$.

\section{Glucagon}

Glucagon is secreted by the $\alpha$-cells of the pancreatic islets. It has catabolic properties, functioning as a counter-regulatory hormone opposing the actions of insulin. Glucagon maintains blood glucose concentrations during fasting by promoting glycogenolysis and gluconeogenesis as well as by inhibiting glycogenesis and glycolysis in the liver, thereby preventing hypoglycaemia ${ }^{(210,211)}$. Obese patients exhibit increased glucagon levels ${ }^{(212,213)}$. Inappropriately elevated concentrations of insulin and glucagon, together with insulin resistance, contribute to the obesity-associated impaired glucose homeostasis ${ }^{(214)}$.

Glucagon exerts many extrahepatic actions. It increases lipolysis in adipose tissue and reduces food intake, acting as a satiety factor in the brain ${ }^{(211)}$. In humans, pharmacological doses of glucagon decrease the amount of food that is eaten ${ }^{(215)}$. Although this effect was initially attributed to an indirect action of glucagon via the increase in portal glucose levels ${ }^{(216)}$, it has been clearly demonstrated that glucagon has central actions in the brain to reduce food intake ${ }^{(217)}$. Administration of glucagon has been shown to produce weight loss in humans and rats ${ }^{(218,219)}$. This can be explained by the fact that glucagon causes an increase in energy expenditure ${ }^{(220)}$ via activation of $B A T^{(219)}$. The effect of glucagon on human BAT remains to be fully clarified. However, this effect of glucagon promoting energy expenditure contrasts with the phenotype observed in glucagon receptor knockout mice that exhibit lower adiposity, despite having normal growth rates, body weight, food intake and resting energy expenditure ${ }^{(221)}$. Similar striking observations are reported for mice lacking synaptotagmin-7, a Ca sensor for insulin and glucagon granule exocytosis, which show normal insulin concentrations but severely reduced glucagon levels. This mouse model exhibits a lean phenotype with increased lipolysis and energy expenditure ${ }^{(222)}$. A potential counter-regulatory increase in GLP-1 in mice lacking glucagon signalling could explain these discrepancies ${ }^{(223)}$.

\section{Pancreatic polypeptide}

$\mathrm{PP}$ is a thirty-six-amino acid peptide belonging to the family of peptides including NPY and PYY, which is secreted postprandially under vagal control by pancreatic islet PP cells ${ }^{(19,224)}$. Circulating levels of PP are apparently normal in obese patients ${ }^{(225,226)}$ but the rapid increase in response to a meal observed in healthy subjects is significantly impaired in obese individuals ${ }^{(227,228)}$.

Peripheral administration of PP acutely reduces food intake and gastric emptying and increases energy expenditure in mice, whereas repeated administration during 2 weeks leads to reductions in body weight gain ${ }^{(229)}$. Similar effects are observed in transgenic mice overexpressing $\mathrm{PP}^{(230)}$. The anorectic effect is mediated through Y 4 receptors and is associated with reduced expression of NPY and orexin mRNA in the hypothalamus, being dependent on intact vagal signalling ${ }^{(229)}$. In humans, intravenous infusion of PP leads to delayed gastric emptying and reduced cumulative $24 \mathrm{~h}$ food intake $^{(231,232)}$. To our knowledge, there are no data reporting the effect of PP on energy expenditure in humans.

\section{Amylin}

Amylin, a peptide co-secreted with insulin postprandially by pancreatic $\beta$-cells and, therefore, also named islet amyloid polypeptide, was firstly isolated from diabetic human pancreas ${ }^{(233)}$. Amylin inhibits gastric emptying as well as gastric acid and glucagon secretion ${ }^{(19,234,235)}$. Increased circulating concentrations of amylin have been reported in obese rats and humans, suggesting a role for amylin in the pathophysiology of obesity ${ }^{(236)}$.

Central or peripheral administration of amylin decreases meal size and food intake by promoting meal-ending satiation ${ }^{(235)}$. The anorectic effects of amylin, in contrast to other gut peptides, take place primarily in the area postrema, showing synergy with PYY, CCK and leptin ${ }^{(237)}$. Mechanistic studies in rodents suggest that amylin reduces body weight in a fat-specific manner, preserving lean mass ${ }^{(237)}$. The synthetic amylin analogue pramlintide is prescribed for the treatment of diabetes but also causes mild progressive weight loss in humans ${ }^{(238)}$. Furthermore, pramlintide also exhibits synergic effects with leptin after 20 weeks of treatment in overweight and obese volunteers ${ }^{(239)}$. In addition to its role eliciting satiety, amylin appears to influence energy balance by increasing energy expenditure ${ }^{(240-242)}$. Amylin administration increases lipid utilisation, as indicated by a lower respiratory quotient, reducing adiposity ${ }^{(243)}$. Finally, it has been suggested that amylin could prevent the compensatory decrease in energy expenditure that typically takes place during or after weight loss ${ }^{(235)}$.

\section{Signals from the gut}

The gastrointestinal tract is the largest endocrine organ in the body, representing an important source of regulatory 
hormones ${ }^{(244)}$. The gut uses neural and endocrine pathways to coordinately regulate food intake and energy expenditure in the hypothalamus ${ }^{(245)}$. Ghrelin is considered the only circulating orexigenic hormone, which seems to act as a meal initiator ${ }^{(246)}$. Satiety signals derived from the gut include GLP-1, PYY, CCK and oxyntomodulin, among others ${ }^{(234,244,245,247,248)}$. Recently, the existence of another peptide, prouroguanylin, produced by the intestine and with satiating effects has been reported ${ }^{(16)}$.

\section{Ghrelin}

Ghrelin is a twenty-eight-amino acid peptide secreted by oxyntic cells in the stomach fundus. Ghrelin was first characterised as a natural ligand of the growth hormone secretagogue receptor ${ }^{(249)}$. In subsequent studies ghrelin was shown to participate in the complex entero-hypothalamic control of food intake signalling ${ }^{(250)}$. Central or peripheral administration of ghrelin increases food intake and adiposity in rodents ${ }^{(251,252)}$ and humans ${ }^{(253,254)}$. In humans, plasma ghrelin concentrations have been shown to rise shortly before and fall quickly after every meal, suggesting a role in meal initiation ${ }^{(255)}$. Ghrelin concentrations are decreased in human obesity ${ }^{(256)}$, which has been explained as a physiological adaptation to the positive energy balance associated with obesity, and increase in response to diet-induced weight loss ${ }^{(257)}$. However, many studies have shown that ghrelin concentrations do not increase after surgically induced weight loss following procedures that compromise the functionality of the fundus ${ }^{(258,259)}$, while other studies have reported an increase in ghrelin levels following bariatric surgery ${ }^{(260)}$.

Chronic central or peripheral administration of ghrelin increases cumulative food intake and decreases energy expenditure, resulting in body weight gain ${ }^{(250,251,253,261)}$. The orexigenic effect of ghrelin is mediated by the activation of NPY/AgRP, since ghrelin does not stimulate feeding in NPY and AgRP double knockout mice ${ }^{(262)}$, and it is also mediated by the inhibition of hypothalamic fatty acid biosynthesis ${ }^{(263)}$. In this sense, the absence of ghrelin or its receptors protects against the development of early-onset obesity $^{(264,265)}$ and mice lacking simultaneously ghrelin and its receptor exhibit an increased energy expenditure $^{(266)}$. Therefore, ghrelin signalling inhibition has been suggested as a potential therapeutic tool in obesity treatment, whereas a direct therapeutic application of ghrelin can be contemplated for the treatment of cachexia and anorexia ${ }^{(248)}$. In this sense, intravenous administration of ghrelin results in weight gain in patients with cardiac cachexia and chronic obstructive pulmonary disease ${ }^{(267,268)}$

\section{Glucose-dependent insulinotropic polypeptide}

Insulin secretion is higher in response to orally administered than to intravenous glucose administration. This is known as the incretin effect ${ }^{(269)}$. Originally named gastric inhibitory polypeptide, glucose-dependent insulinotropic polypeptide (GIP) was the first incretin identified ${ }^{(270)}$. The major stimulus for GIP secretion is nutrient intake. GIP is mainly secreted by $\mathrm{K}$ cells in the duodenum and jejunum ${ }^{(269,271)}$. Circulating concentrations of GIP are low in the fasting state and rise within minutes following food intake. Moreover, GIP levels increase after a high-fat diet, with postprandial GIP secretion being significantly higher in obese subjects than in age-matched lean individuals ${ }^{(271,272)}$. In addition to its role in regulating insulin secretion, GIP stimulates $\beta$-cell replication and mass expansion at the same time as it stimulates glucagon secretion ${ }^{(273,274)}$. In addition, GIP inhibits gastric acid secretion and gastric emptying, although only at supraphysiological doses ${ }^{(275)}$.

The GIP receptor (GIPR) is present in adipose tissue, regulating adipocyte growth, and there is a large body of biochemical and animal data suggesting that GIP signalling promotes fat accumulation ${ }^{(271,276-278)}$. Chemical or genetic ablation of GIP signalling or targeted reduction of GIP-secreting cells does not modify food intake ${ }^{(278-281)}$. However, the absence of GIP signalling produces a significant increase in energy expenditure, protecting from highfat diet-induced obesity and insulin resistance ${ }^{(278,279,281)}$. Moreover, peripheral administration of synthetic human GIP reduces energy expenditure in healthy subjects but not in patients with $\mathrm{T}_{2} \mathrm{DM}^{(282)}$. Furthermore, emerging evidence suggests that the rapid resolution of diabetes in morbidly obese patients undergoing bypass surgery is mediated, at least in part, by surgical removal of GIP-secreting cells in the upper small intestine ${ }^{(283)}$. Although inhibiting GIP/GIPR signalling may be beneficial as a treatment for obesity ${ }^{(271)}$, the mechanisms involved in the regulation of food intake and energy expenditure elicited by GIP in humans remain to be fully understood.

\section{Glucagon-like peptide 1}

Through action of prohormone convertases, proglucagon is processed to glicentin, oxyntomodulin, intervening peptides 1 and 2, GLP-1 and GLP-2. To date, only GIP and GLP-1 are considered to be incretin hormones in humans, being responsible for as much as $50 \%$ of postprandial insulin secretion ${ }^{(274,284)}$. GLP-1 is mainly produced by L-cells in the ileum after meals; in addition to its role as an insulinotropic hormone it participates actively in regulating gastric motility, islet $\beta$-cell neogenesis, neuronal plasticity and the suppression of plasma glucagon concentrations $^{(285,286)}$. Although a clear role for GLP-1 in the aetiology of T2DM has not been proved, a common view states that GLP-1 secretion in patients with T2DM is deficient $^{(287)}$. Similarly, some controversies exist regarding the involvement of GLP-1 in obesity pathophysiology. It has been suggested that obesity is associated with reduced secretion of GLP-1 ${ }^{(288-290)}$, which is restored to normal 
levels after weight loss ${ }^{(291)}$, particularly following malabsorptive bariatric surgery ${ }^{(292)}$.

GLP-1 has an important role in food intake regulation, promoting satiety ${ }^{(293-295)}$ even in obese men ${ }^{(296,297)}$, acting as a short-term satiation signal, limiting the amount of food eaten and prolonging time between meals ${ }^{(298)}$. Another important action of this incretin in relation to energy homeostasis is the inhibition of gastric emptying following GLP-1 administration, with the vagus nerve playing an important role ${ }^{(286,297)}$. Intravenous administration of GLP-1 increases postprandial energy expenditure via the lower brainstem and the sympathoadrenal system in rats ${ }^{(299)}$. Exogenous administration of GLP-1 to humans reduces postprandial thermogenesis, which can be explained by a reduction in meal size ${ }^{(297)}$. However, higher fasting plasma concentrations of GLP-1 are associated with higher resting energy expenditure and fat oxidation rates in humans ${ }^{(300)}$. Data regarding energy expenditure from mice deficient in GLP-1 signalling are conflicting, with some studies finding that loss of function protects against the development of diet-induced obesity by increasing energy expenditure $^{(281,301,302)}$, while others show that loss of GLP-1 signalling increases fat accumulation ${ }^{(303,304)}$. These differences may be related to species-specific differences and effects on locomotor activity ${ }^{(305)}$.

GLP-1 signalling is a potential target for the treatment of both T2DM and obesity. In this sense, liraglutide, a GLP-1 analogue with a prolonged half-life initially developed for the treatment of T2DM, has shown additional beneficial features for body weight control ${ }^{(306,307)}$. In this context, activation of the GLP-1 receptor is currently proposed as the most effective drug for treating the metabolic syndrome ${ }^{(308)}$.

GLP-2 has also been involved in the regulation of food intake ${ }^{(309)}$. However, deletion of GLP-2 receptor signalling in $o b / o b$ mice impairs the normal islet adaptive response needed for maintaining glucose homeostasis but has no effect on body weight or food intake ${ }^{(310)}$. GLP-2 has also been associated with gut hypertrophy and intestinal crypt cell proliferation after gastric bypass ${ }^{(311)}$ but has no effect on energy expenditure ${ }^{(299)}$.

Further evidence of the important involvement of incretins in energy homeostasis arises from studies involving dipeptidyl peptidase 4 (DPP-4). DPP-4 is a member of the prolyl oligopeptidase family of peptidases and is the key enzyme responsible for cleaving and inactivating GIP and GLP- ${ }^{(312)}$. Mice lacking DPP-4 exhibit improved glucose tolerance and insulin sensitivity as well as resistance to diet-induced obesity, which can be explained by reduced food intake and increased energy expenditure ${ }^{(313)}$.

\section{Peptide YY}

PYY is a thirty-six-amino acid gut hormone so called after the tyrosine residues at each terminus of the peptide that belongs to the NPY family ${ }^{(314,315)}$. It is secreted mainly from specialised enteroendocrine cells, called L-cells, of the distal gut, with the highest production being in the ileum and colon. Two main endogenous forms of PYY exist, $\mathrm{PYY}_{1-36}$ and $\mathrm{PYY}_{3-36}$. $\mathrm{PYY}_{3-36}$ is the dominant circulating form of the peptide both in the fasted and fed states, accounting for $60 \%$ of postprandial circulating PYY ${ }^{(316,317)}$. Circulating concentrations of PYY rise within 15 min after nutrient ingestion. $\mathrm{PYY}_{1-36}$ has specificity for $\mathrm{Y} 1$ and $\mathrm{Y} 5$ receptors, increasing food intake. However, $\mathrm{PYY}_{3-36}$ binds preferentially to Y2 receptors, thereby stimulating anorectic pathways ${ }^{(318)}$. Lower levels of $\mathrm{PYY}_{3-36}$ have been reported in obese individuals, suggesting that this gut hormone has a role in the pathophysiology of obesity ${ }^{(319)}$.

Peripheral injection of $\mathrm{PYY}_{3-36}$ has been shown to reduce food intake and to induce a negative energy balance in mice and rats ${ }^{(320)}$, monkeys ${ }^{(321)}$ and humans ${ }^{(320)}$, even in obese patients ${ }^{(319)}$. This occurs through modulation of different cortical and hypothalamic brain $\operatorname{areas}^{(322)}$. However, these anorexigenic effects of $\mathrm{PYY}_{3-36}$ have not been confirmed by others ${ }^{(323)}$. Furthermore, despite the effects of $\mathrm{PYY}_{3-36}$ on food intake inhibition, mice lacking Pyy do not exhibit a clear phenotype, showing normal feeding behaviour, growth and energy expenditure ${ }^{(324,325)}$, or even obesity ${ }^{(326,327)}$. Intravenous administration of $\mathrm{PYY}_{3-36}$ increases lipolysis and energy expenditure in humans ${ }^{(328)}$, with total PYY being significantly correlated with postprandial energy expenditure $^{(329)}$. However, this association has not been unequivocally found ${ }^{(330)}$. The extent of $\mathrm{PYY}_{3-36}$ involvement in the regulation of energy homeostasis and the underlying mechanisms mediating the effects of $\mathrm{PYY}_{3-36}$ on energy expenditure in humans are still not fully understood.

\section{Cholecystokinin}

CCK is secreted mainly by I-cells in the proximal small intestine in response to lipids and proteins in the meal ${ }^{(19,234,331)}$. The predominant circulating forms of CCK in rodents include CCK octapeptide (CCK-8) and CCK-22, whereas larger molecular forms are also present in human plasma ${ }^{(332)}$. CCK is involved in modulating intestinal motility, stimulating pancreatic enzyme secretion, enhancing gallbladder contraction and regulating meal size but not meal frequency ${ }^{(333)}$. A total of two CCK receptors have been cloned so far: CCK1R and CCK2R. Selective CCK1R antagonists block the anorectic effect of CCK, whereas selective antagonism of CCK2R has no effect on food intake ${ }^{(234,334-336)}$.

The satiating effect of CCK was first described more than three decades ago ${ }^{(337)}$, with vagotomy suppressing the anorectic effects of peripheral $\mathrm{CCK}^{(338)}$. In humans, intravenous infusion of CCK induces a dose-dependent suppression of food intake ${ }^{(339)}$. Administration of CCK before the start of a meal does not delay the onset of eating, but rather reduces the amount of food consumed once eating begins ${ }^{(12)}$. 
However, long-term CCK1R stimulation failed to produce significant weight loss in obese patients due to the rapid development of tolerance ${ }^{(340,341)}$, thereby questioning the potential of CCK as an anti-obesity target ${ }^{(234)}$.

Rats deficient in CCK1R show increased meal size and obesity $^{(342)}$. However, mice lacking CCK or CCK1R exhibit a normal food intake and body weight, apparently indicating that CCK is not essential for the long-term maintenance of body weight ${ }^{(333,335)}$. Interestingly, CCK knockout mice fed on a high-fat diet develop protection against obesity despite having a normal food intake, probably through decreased lipid absorption and increased energy expenditure ${ }^{(336)}$.

\section{Oxyntomodulin}

Oxyntomodulin is another cleavage product of proglucagon secreted by intestinal L-cells after meals in proportion to the energy content of foods ${ }^{(343,344)}$. It was named oxyntomodulin after its inhibitory action on the oxyntic glands of the stomach ${ }^{(345)}$. Oxyntomodulin inhibits gastric acid secretion and pancreatic enzyme secretion ${ }^{(346)}$. Although no oxyntomodulin receptor has been identified yet, it appears that the actions of oxyntomodulin are mediated via the GLP-1 receptor ${ }^{(347)}$, since the anorectic effect of oxyntomodulin is abolished in GLP-1 receptordeficient mice ${ }^{(348)}$. However, GLP-1 and oxyntomodulin appear to activate different hypothalamic pathways ${ }^{(349)}$ and, therefore, a separate unidentified oxyntomodulin receptor may exist ${ }^{(315)}$.

Central or peripherally administered oxyntomodulin inhibits food intake in fasted and non-fasted rats ${ }^{(350,351)}$ However, the anorectic effect in mice is only observed after intracerebroventricular administration ${ }^{(348)}$. Intravenous administration of oxyntomodulin suppresses appetite and reduces food intake in humans ${ }^{(352)}$. Furthermore, subcutaneous injections of oxyntomodulin resulted in weight loss and a change in the levels of adipokines consistent with a loss of body fat over a 4-week period in overweight and obese subjects ${ }^{(353)}$. Central administration of oxyntomodulin increases energy expenditure and causes a disproportionate reduction in body weight compared with pair-fed rats ${ }^{(351,354)}$. In humans, $4 \mathrm{~d}$ subcutaneous self-administration of pre-prandial oxyntomodulin three times per d promotes a negative energy balance, increasing energy expenditure while reducing energy intake ${ }^{(355)}$. However, the acute thermogenic effect of oxyntomodulin observed in rats and humans has not been reproduced in mice $^{(348)}$. Further studies are needed in order to investigate whether the effect of oxyntomodulin on energy expenditure in humans is maintained in the long term, but data presented above support the role of oxyntomodulin as a potential anti-obesity tool.

\section{Uroguanylin}

Guanylin and uroguanylin have been well-known key paracrine players in intestinal ion and water balance for over 20 years, acting as endogenous ligands of guanylyl cyclase (GUCY) 2C and increasing cyclic guanosine monophosphate (cGMP) production ${ }^{(356)}$. They are secreted by intestinal epithelial cells as prohormones, requiring proteolytic enzymic conversion into active hormones in the target tissue $^{(357)}$. Physiological functions for these molecules include the modulation of epithelial cell balance in the intestinal epithelium and the regulation of $\mathrm{Na}$ balance through actions on the kidney ${ }^{(358)}$. Recently, Valentino et $a l .{ }^{(16)}$ revealed a new endocrine role for uroguanylin in energy homeostasis. The uroguanylin precursor, prouroguanylin, is secreted into the circulation after meals in both mice and humans; it can then be cleaved to uroguanylin in the hypothalamus to activate GUCY2C for decreasing food intake $^{(16)}$. Deletion of GUCY2C in mice disrupts appetite regulation specifically by impairing satiation, producing hyperphagia associated with obesity and glucose intolerance $^{(16)}$. No changes in cold-induced thermogenesis assessed by core body temperature were observed ${ }^{(16)}$. However, the role of uroguanylin in the modulation of energy expenditure needs to be addressed in both rodents and humans. Furthermore, it has been suggested that uroguanylin could exert a direct effect on adipose tissue, regulating lipolysis ${ }^{(359)}$, given the fact that cGMP is a second messenger known to be involved in the lipolytic effect of natriuretic peptides, which are closely related to uroguany$\operatorname{lin}^{(360)}$. The uroguanylin-GUCY2C endocrine axis may offer a novel therapeutic target for regulating food intake and a weapon against obesity ${ }^{(16,359)}$.

\section{Fibroblast growth factor 19}

The family of fibroblast growth factors (FGF) regulates a plethora of processes including organ development, the maintaining of bile acid homeostasis and the activation of hepatic protein and glycogen synthesis ${ }^{(361,362)}$. FGF19 is expressed in the distal small intestine, with the concentration of circulating FGF19 increasing in response to feeding. Transgenic mice expressing human FGF19 exhibit an increased metabolic rate and decreased adiposity despite having increased food intake with an increase in fatty acid oxidation $^{(363,364)}$. However, in addition to its metabolic actions FGF19 also has proliferative effects, with transgenic mice developing hepatocellular carcinoma within 1 year, thereby rendering FGF19, a priori, unsuitable as a candidate for combating obesity ${ }^{(365)}$.

\section{Signals from the liver}

The liver plays an important role in energy homeostasis $^{(366)}$. Due to its anatomical position the liver has rapid access to incoming nutrients from intestinal absorption. In addition to its role in regulating glucose and fatty acid metabolism, the liver produces several proteins involved in peripheral control of energy homeostasis. 


\section{Insulin-like growth factor system}

Members of the insulin-like growth factor (IGF) system are functionally related to insulin. The IGF regulatory system consists of IGF (IGF-I and IGF-II), type I and type II IGF receptors, and IGF-binding proteins (IGFBP-1-6) ${ }^{(367,368)}$. IGF are ubiquitously expressed, although the main source of circulating IGF-I is the liver. They exert actions in almost all tissues and are among the major regulators of growth ${ }^{(368,369)}$. While insulin is a short-term regulator of glucose homeostasis, IGF have been suggested to exert long-term regulation of glucose homeostasis ${ }^{(370-372)}$. Insulin and IGF-I show cross-reactivity at the receptor level. After ligand binding-induced autophosphorylation, insulin receptor and IGF-I receptor catalyse the phosphorylation of cellular proteins such as members of the insulin receptor substrate family ${ }^{(373)}$. Other functions in which IGF play a critical role are the regulation of growth, neuroprotection, tumorigenesis and longevity $^{(372,374,375)}$. Adipose tissue levels of IGF-I have been shown to be higher in both rodent and human obesity ${ }^{(376)}$, although the IGF-I-induced signalling cascade is impaired in obese mice ${ }^{(377)}$.

IGF-I treatment by osmotic minipumps at adult age reduces hyperphagia, obesity, hyperinsulinaemia, hyperleptinaemia and hypertension in rats programmed to develop the metabolic syndrome by fetal programming ${ }^{(378)}$. However, IGF-I administration does not exhibit anorectic effects in sheep ${ }^{(379)}$. Singularly, another study reported that central injection of IGF-II, but not IGF-I, reduces short-term food intake in rats ${ }^{(380)}$. It has been recently reported that IGF-I may play an important role in thermogenesis ${ }^{(375)}$. Administration of IGF-I to the preoptic area, a hypothalamic region involved in the control of thermoregulation, produces hyperthermia involving activation of BAT in mice ${ }^{(375)}$. This thermogenic effect was accompanied by a switch from glycolysis to fatty acid oxidation and appears to be dependent of the insulin receptor, since it is absent in mice lacking the neuronal insulin receptor. These findings suggest a more important role of the IGF system in energy expenditure than previously thought $^{(375)}$

Although IGFBP are generally thought to inhibit the action of IGF through high-affinity binding which prevents interaction with IGF receptors, IGFBP can potentially either inhibit or enhance IGF actions ${ }^{(368,381)}$. Overexpression of IGFBP2 by adenovirus prevents weight gain and hyperglycaemia in diet-induced obese mice ${ }^{(382)}$. Moreover, it reverses diabetes at the same time as reducing food intake and inhibits body weight gain in insulin-resistant $o b / o b$ mice by unexplored mechanisms ${ }^{(383)}$.

\section{Fibroblast growth factor 21}

FGF21 is a pleiotropic hormone-like protein that has emerged as a major regulator of energy homeostasis ${ }^{(384)}$.
Production of FGF21 takes place mainly in the liver ${ }^{(385)}$ and is regulated by PPAR ${ }^{(386)}$. FGF21 has been shown to be a major regulator of hepatic lipid metabolism in ketotic states, being up-regulated during fasting ${ }^{(386,387)}$. FGF21 transgenic mice are resistant to diet-induced obesity, with FGF21 administration reducing serum glucose and TAG levels in obese and diabetic $o b / o b$ and $d b / d b$ mice $^{(388)}$. In humans, FGF21 correlates with BMI and may be a novel biomarker for fatty liver ${ }^{(389)}$. Since the expected beneficial effects of endogenous FGF21 for improving glucose tolerance and reducing TAG levels are absent in obese mice and men, obesity has been proposed to be a FGF21-resistant state ${ }^{(390)}$.

Intraperitoneal injections or central administration of FGF21 increases energy expenditure, improves insulin sensitivity and reverses hepatic steatosis in diet-induced obese mice $^{(391)}$ and rats ${ }^{(392)}$. The thermogenic effect may be related to the activation of BAT, since it has been reported that this adipose depot may be a source of FGF in response to cold, exhibiting an autocrine role in the stimulation of thermogenesis ${ }^{(393)}$. Although the wide interindividual variation in serum FGF21 observed in humans raises some doubts regarding its therapeutic relevance ${ }^{(384)}$, the reported metabolic effects of FGF21 highlight the need for more research in order to assess the use of FGF21 for treating metabolic diseases.

\section{Sex hormone-binding globulin}

Sex hormone-binding globulin (SHBG) transports androgens and oestrogens in blood and regulates their access to target tissues ${ }^{(394)}$. SHBG is mainly produced by hepatocytes and its secretion fluctuates, being primarily influenced by metabolic and hormonal factors ${ }^{(394)}$. Obesity results in reduced hepatic synthesis and blood concentrations of SHBG, with blood levels of SHBG correlating negatively with energy expenditure in postmenopausal women $^{(395)}$ and with fat accumulation in men ${ }^{(396)}$. Moreover, low circulating concentrations of SHBG are a strong predictor of the risk of T2DM in men and women ${ }^{(397)}$ as well as of the metabolic syndrome in non-obese men ${ }^{(194)}$. This finding has been related to the suppressive effect of insulin on SHBG. Furthermore, the combined effect of increased levels of sex hormones previously mentioned, together with the reduced concentrations of SHBG, leads to an increase in the bioavailable androgens and oestrogens which may promote cellular proliferation and inhibit apoptosis in target cells, thereby being involved in the increased risk of cancer associated with obesity ${ }^{(398)}$.

\section{Signals from skeletal muscle}

In humans, skeletal muscle represents $40 \%$ of the total body mass and accounts for approximately 20-30\% of the total resting oxygen uptake ${ }^{(399)}$. A large part of the adaptive thermogenic response is determined by skeletal 
muscle via the process of mitochondrial uncoupling ${ }^{(400)}$. Furthermore, skeletal muscle secretes myostatin, which has been shown to play a role in energy homeostasis ${ }^{(17)}$. Exercise is well known to exert beneficial effects on energy balance control. Recently, irisin has been identified as an exercise-induced hormone secreted by skeletal muscle that promotes brown adipocyte recruitment in white fat, thereby increasing energy expenditure ${ }^{(401)}$.

\section{Myostatin}

Myostatin is a secreted member of the transforming growth factor- $\beta$ (TGF- $\beta$ ) family that acts as a negative regulator of skeletal muscle growth by signalling through activin receptors ${ }^{(402)}$. During adulthood, the myostatin protein is produced by skeletal muscle, circulates in the blood, and limits muscle mass ${ }^{(402)}$. Myostatin is expressed almost exclusively in skeletal muscle, although detectable levels of myostatin mRNA are also present in adipose tissue. Myostatin overexpression in mice induces a dramatic loss of muscle and adipose tissue mass with normal food intake ${ }^{(403)}$. The loss of fat is concordant with the capacity of myostatin to block adipogenesis ${ }^{(404)}$. As can be expected, mice lacking myostatin exhibit increased muscle mass but, surprisingly, show reduced adiposity ${ }^{(405)}$. This finding can be explained by an increased fatty acid oxidation in peripheral tissues through the stimulation of enzymes involved in lipolysis and in mitochondrial fatty acid oxidation ${ }^{(406)}$. The decreased fat mass of myostatinnull mice can be further explained by a concomitant stimulation of thermogenesis through the activation of $\mathrm{BAT}^{(406)}$. Inhibition of myostatin signalling either in skeletal muscle or adipose tissue evidenced that body fat loss is an indirect result of metabolic changes in skeletal muscle ${ }^{(407)}$, apparently mediated by increased energy expenditure and leptin sensitivity ${ }^{(17)}$. Interestingly, skeletal muscle myostatin protein levels and plasma concentrations were higher in extremely obese women, with the former being correlated with the severity of insulin resistance ${ }^{(408)}$. Leptin replacement increases muscle mass of $o b / o b$ mice, and this effect is associated with a leptin-induced reduction in the skeletal muscle expression of myostatin ${ }^{(409)}$. However, leptin administration to hypoleptinaemic women did not decrease serum levels of myostatin, suggesting that leptin is not probably involved in the regulation of the myostatin axis in humans, although expression of myostatin in skeletal muscle was not measured ${ }^{(410)}$. Recently, the association of myostatin gene polymorphisms with obesity in humans has been reported, although the pathophysiological mechanisms remain to be elucidated ${ }^{(411)}$

\section{Signals from the kidney}

Under normal circumstances the kidney is not directly involved in energy homeostasis. However, it exerts a notable role in the peripheral control of energy metabolism, secreting primary molecules that participate in the renin-Ang system ${ }^{(174)}$.

\section{Renin}

As mentioned previously, an overactive renin-Ang system has been involved in the development of obesity-associated co-morbidities as well as in energy homeostasis ${ }^{(174)}$. Renin catalyses the rate-limiting step of Ang II production ${ }^{(174)}$. Mice lacking renin exhibit lower blood pressure and undetectable plasma levels of renin, Ang I and Ang $\mathrm{II}^{(412)}$. Unexpectedly, these mice are resistant to dietinduced obesity via an increased metabolic rate and partly through a gastrointestinal loss of dietary fat, but not from increased locomotor activity or reduced food intake $^{(14)}$. Some, but not all, of the observed alterations were reversed after Ang II administration. Furthermore, it has been reported that transgenic rodents overexpressing renin eat significantly more after $24 \mathrm{~h}$ than controls $^{(413)}$ and develop obesity ${ }^{(414)}$ by mechanisms not related to Ang $\mathrm{II}^{(415)}$. These findings suggest that renin inhibitors may be a therapeutic tool against obesity, insulin resistance and their cardiometabolic co-morbidities.

\section{Signals from the heart}

The discovery of atrial natriuretic peptide (ANP) showed that the heart is not only a mechanical organ pumping blood through the blood vessels, but also an endocrine organ involved in the regulation of the cardiovascularrenal system and energy metabolism ${ }^{(416)}$.

\section{Atrial natriuretic peptides}

ANP and brain natriuretic peptide (BNP) are synthesised in the heart and they are considered to exert their predominant effects in lowering blood pressure, controlling blood volume and reducing heart overgrowth in pathological conditions $^{(417)}$. Another related peptide, C-type natriuretic peptide (CNP) is expressed mainly in the central nervous system but also in the vascular endothelial cells and chondrocytes $^{(418)}$. ANP and BNP preferentially bind to GUCY-A, promoting the production of CGMP and the activation of protein kinase $G^{(419)}$. CNP is the physiological ligand for GUCY-B.

All members of the system (natriuretic peptides and their receptors) are expressed in adipose tissue, while their expression levels are altered in obesity ${ }^{(417,420-423)}$. ANP and BNP, but not CNP, have been reported to induce potent lipolytic effects in human adipocytes similar to those exerted by the $\beta$-adrenoceptor agonist isoprotere$\mathrm{nol}^{(360,424)}$. Moreover, ANP inhibits human visceral adipocyte growth in culture at physiological concentrations ${ }^{(425)}$. ANP availability is decreased in obesity, with BMI being inversely correlated to circulating ANP and BNP concentrations ${ }^{(426)}$. 
Besides their physiological role as lipid-mobilising agents, natriuretic peptides are also involved in the regulation of food intake and energy expenditure. CNP suppresses oxygen consumption in BAT in mice by attenuating the sympathetic nervous system activity, possibly under the control of the hypothalamus ${ }^{(427)}$. Furthermore, it has been shown that natriuretic peptides can promote muscle mitochondrial biogenesis and fat oxidation, preventing the development of obesity and insulin resistance in mice ${ }^{(428)}$. In this sense, intravenously administered ANP induces postprandial lipid oxidation in humans and increases energy expenditure ${ }^{(429)}$. These findings suggest that natriuretic peptides may represent a promising therapeutic tool for combating obesity and T2DM.

\section{Signals from the thyroid gland}

The thyroid gland, through the production of thyroid hormones, is a major determinant of overall energy expenditure and $\mathrm{BMR}^{(430)}$.

\section{Thyroid hormones}

The thyroid gland produces the parental form of thyroid hormone, thyroxine (T4), and lower amounts of the major active form of thyroid hormone, triiodothyronine $(\mathrm{T} 3)^{(431)}$. T3 is produced by deiodination of $\mathrm{T} 4$ in target cells by specific deiodinases. Secretion of $\mathrm{T} 4$ by the thyroid gland is stimulated by thyroid-stimulating hormone secreted by the pituitary gland ${ }^{(432)}$. Thyroid hormones bind to thyroid hormone receptor (THR) $\alpha$ and THR $\beta$, which are members of the nuclear hormone receptor family ${ }^{(433)}$. Thyroid hormones affect numerous cellular processes that are relevant for energy homeostasis ${ }^{(430)}$. Thyroid-stimulating hormone is usually moderately increased in obesity, which is a consequence rather than a cause of obesity ${ }^{(434)}$. Alterations in thyroid hormones affect body weight. Hypothyroidism is frequently associated with a modest weight gain, decreased metabolic rate and cold intolerance, whereas hyperthyroidism is related to weight loss despite increased appetite and elevated metabolic rate ${ }^{(434,435)}$.

Hyperthyroidism in humans and rodents causes increased food intake but reduced body weight compared with euthyroid controls due to increased energy expenditure. The increase in oxygen consumption and body temperature is accompanied by enhanced fatty acid oxidation $^{(431)}$. Evidence of the critical role of thyroid hormones on energy homeostasis arises from genetic mouse models lacking $\mathrm{THR}^{(436,437)}$. Mice lacking $\mathrm{THR}^{(438)}$ or THR $\beta^{(439)}$ exhibit reduced thermogenesis as well as other metabolic alterations. Although the involvement of thyroid hormones in energy homeostasis is critical, the physiological mechanisms explaining this effect remain elusive. The thermogenic effect of thyroid hormones has been related to accelerated ATP turnover and reduced efficiency of ATP synthesis as well as to changes in the efficiency of metabolic processes downstream from the mitochondria 'futile and substrate cycles'(430,435). Peripheral administration of T3 increases food intake but also energy expenditure $^{(440)}$. An increase in hypothalamic AMPK may be mediating the orexigenic effect of $\mathrm{T}^{(441)}$. Similarly, it has been recently described that besides the critical role of T3 stimulating thermogenesis in skeletal muscle ${ }^{(430)}$, thyroid hormone-induced modulation of AMPK activity and lipid metabolism in the hypothalamus and subsequent thermogenic activation of BAT is a major regulator of whole-body energy homeostasis ${ }^{(442)}$. Although the information available makes the thyroid system an interesting field for the development of therapeutic drugs in the fight against obesity, available data regarding effectiveness of thyroid hormone therapy for treating obesity are inconclusive $^{(443)}$.

\section{Signals from bone}

Both body fat mass and fat-free mass correlate directly with bone mineral density. Obesity has been proposed to exert a protective role in the development of osteoporosis ${ }^{(444)}$. On the contrary, low BMI is a risk factor for low bone quality and osteoporosis which is largely independent of age and $\operatorname{sex}^{(445)}$. There is a putative 'endocrine' interplay between adipose tissue and bone, with adipokines and molecules secreted by osteoblasts and osteoclasts (osteokines) being the links of a bone-adipose tissue axis ${ }^{(15)}$. In this sense, recent findings suggest that osteokines may exert an endocrine regulation on glucose homeostasis and body weight ${ }^{(15,446)}$.

\section{Osteopontin}

Osteopontin, also known as secreted phosphoprotein-1, bone sialoprotein- 1 and early $\mathrm{T}$ lymphocyte activation (Eta-1) is a phosphoprotein expressed by a wide variety of cell types, such as osteoclasts, macrophages, hepatocytes and vascular smooth muscle cells, among others $^{(447)}$. Osteopontin exerts important actions on bone turnover, serving as attachment for osteoclasts activating resorption ${ }^{(447,448)}$. In addition to bone remodelling, osteopontin is also involved in several pathophysiological processes including inflammation, immunity, neoplastic transformation, progression of metastases, wound healing and cardiovascular function ${ }^{(447)}$. Osteopontin has been shown to be also produced by adipocytes and to play an important role in obesity and obesity-associated insulin resistance ${ }^{(39,449-453)}$. Expression of osteopontin is dramatically increased in adipose tissue from obese individuals ${ }^{(449,454,455)}$, suggesting the important role that this protein has in the molecular alterations that take place during adipose tissue enlargement. Moreover, osteopontin has been suggested to play a pivotal role linking obesity to 
insulin resistance development by promoting inflammation and the accumulation of macrophages in adipose tissue $^{(450,453,456)}$. Higher levels of expression of osteopontin have been shown to be related to macrophage accumulation in adipose tissue and to liver steatosis in morbidly obese subjects ${ }^{(457)}$, which promote fibrosis progression in non-alcoholic steatohepatitis ${ }^{(458)}$. Furthermore, it has been recently shown that osteopontin expression is increased in omental adipose tissue of colon cancer patients, suggesting a potential role of osteopontin linking increased inflammation in visceral adiposity with neoplastic processes ${ }^{(459)}$.

\section{Osteocalcin}

Osteocalcin is a non-collagenous protein marker of osteoblastic activity thought to play a role in mineralisation and Ca homeostasis ${ }^{(460)}$. Osteocalcin is secreted mainly by osteoblasts and its levels decrease in malnutrition, starvation and anorexia nervosa. Osteocalcin has been traditionally considered as a biological marker of bone formation $^{(460)}$ but now has also been shown to play a role in the regulation of metabolism and in the development of $\mathrm{CVD}^{(461-463)}$.

The regulation of bone remodelling by leptin led to the hypothesis that bone exerts a role in the feedback control of energy homeostasis ${ }^{(464)}$. In this sense, mice lacking the osteoblast-secreted molecule osteocalcin exhibit an increased adiposity and insulin resistance ${ }^{(464,465)}$. Osteocalcin is able to improve glucose tolerance in vivo through the stimulation of the expression of insulin and $\beta$-cell proliferation and the induction of the expression of adiponectin and genes involved in energy expenditure in adipocytes $^{(464,466)}$. In this sense, administration of osteocalcin improves glucose metabolism and prevents the development of T2DM in mice ${ }^{(466,467)}$.

Serum osteocalcin levels are positively associated with insulin sensitivity and secretion in non-diabetic subjects as well as in patients with type 2 diabetes ${ }^{(462,468)}$. Interestingly, osteocalcin concentrations are reduced in obese individuals and increase after weight loss in parallel to the reduction in visceral fat mass ${ }^{(469)}$. Finally, a recent work suggests that further molecules secreted by bone, yet to be identified, affect energy metabolism ${ }^{(470)}$.

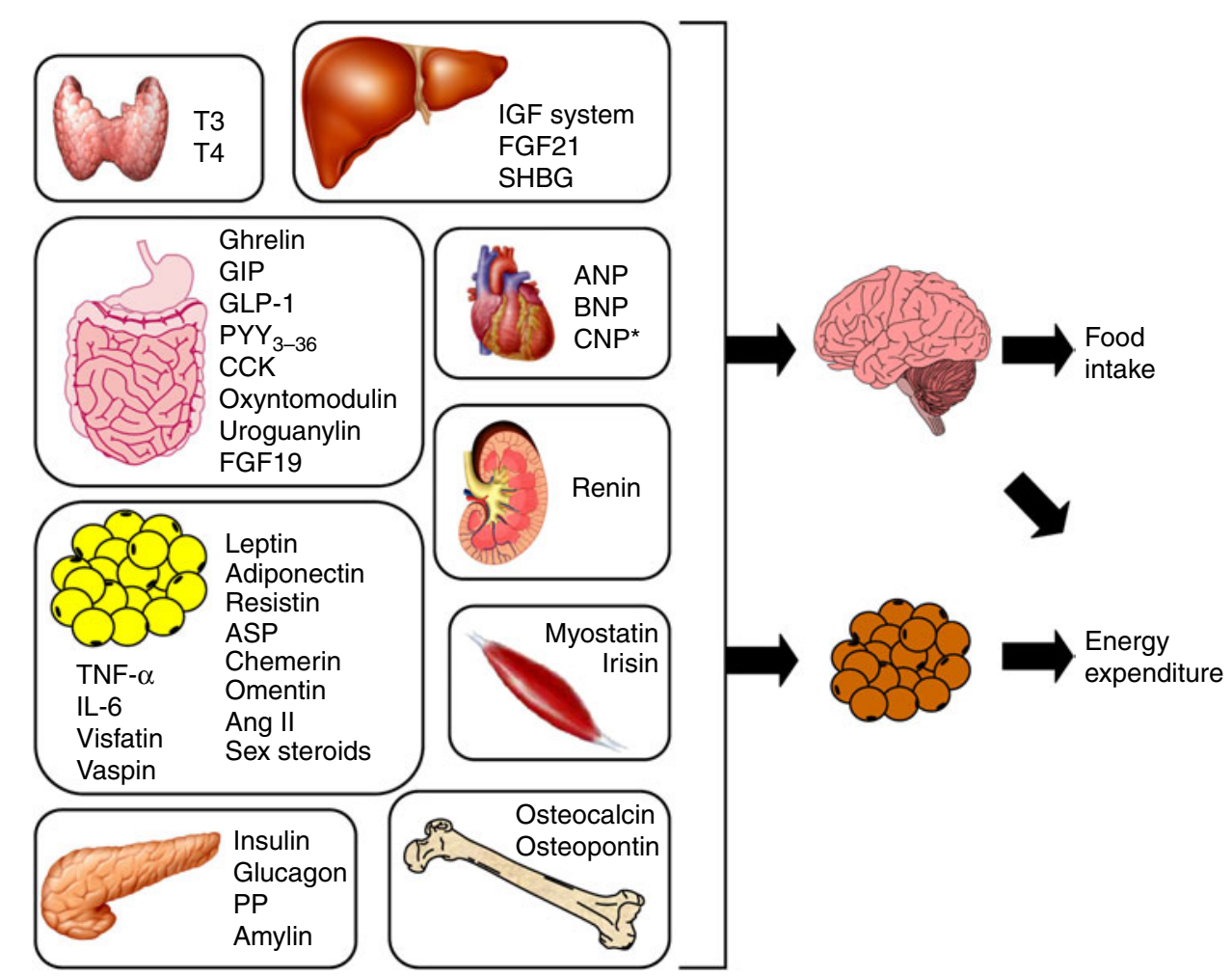

Fig. 1. Peripheral factors exerting a direct effect on energy homeostasis grouped by source organ or system. Although due to their multiple production organs some of the elements might be included in more than one organ or system, they have been included only under one organ or system for simplicity reasons. These molecules play an important role in energy homeostasis mainly, but not uniquely, through direct actions on the brain regulation of food intake and on the thermogenic activity of brown adipose tissue (BAT). In some cases, the effect on BAT activation is mediated via the hypothalamus. Ang II, angiotensin II; ANP, atrial natriuretic peptide; ASP, acylation-stimulating protein; BNP, brain natriuretic peptide; CCK, cholecystokinin; CNP, c-type natriuretic peptide; FGF19, fibroblast growth factor-19; FGF21, fibroblast growth factor-21; GIP, glucose-dependent insulinotropic polypeptide; GLP-1, glucagon-like peptide-1; IGF, insulin-like growth factor; PP, pancreatic polypeptide; $\mathrm{PYY}_{3-36}$, peptide $\mathrm{YY}$ (peptide tyrosine-tyrosine); SHBG, sex hormone-binding globulin; T3, triiodothyronine; T4, thyroxine. ${ }^{*}$ Although CNP is mainly expressed in the central nervous system, it is also expressed in vascular cells (A colour version of this figure can be found online at http://www.journals.cambridge.org/nrr). 


\section{Conclusions}

In summary, adipose tissue mass and energy homeostasis are regulated by a wide array of molecules derived not only by adipose tissue and the pancreas but also by the gut, liver, skeletal muscle, kidney, heart, thyroid gland and bone. This implies that the control of energy homeostasis is more complex than previously described and that the hypothalamus integrates hundreds of signals from many different peripheral organs. Moreover, many of these signals are able to stimulate thermogenesis in organs such as BAT and skeletal muscle (Fig. 1). The comprehension of these signals will help to better understand the aetiopathology of obesity and will contribute to the development of new therapeutic targets aimed at tackling excess body fat accumulation. More exact and precise knowledge regarding the complex interplay between the diverse and numerous peripheral signals as well as the pathophysiological alterations that take place in the different organs will lead to a better understanding of energy homeostasis and the causes and pathogenesis of obesity.

\section{Acknowledgements}

The present review was supported by grants from the Instituto de Salud Carlos III (ISCIII; no. FIS PI081146, PS09/ 02330, PI09/91029 and PI11/02681) and the Departments of Health (3/2006 and 31/2009) and Education (res228/ 2008) of the Gobierno de Navarra. CIBER de Fisiopatología de la Obesidad y Nutrición (CIBERobn) is an initiative of the ISCIII, Spain. The authors gratefully acknowledge Laura Stokes for the diligent English editing of the manuscript.

All authors have contributed to the writing and revision of the text and have approved the final manuscript.

There are no conflicts of interest to declare.

\section{References}

1. Swinburn BA, Sacks G, Hall KD, et al. (2011) The global obesity pandemic: shaped by global drivers and local environments. Lancet 378, 804-814.

2. Finucane MM, Stevens GA, Cowan MJ, et al. (2011) National, regional, and global trends in body-mass index since 1980: systematic analysis of health examination surveys and epidemiological studies with 960 country-years and 9.1 million participants. Lancet 377, 557-567.

3. Kahn SE, Hull RL \& Utzschneider KM (2006) Mechanisms linking obesity to insulin resistance and type 2 diabetes. Nature 444, 840-846.

4. Van Gaal LF, Mertens IL \& De Block CE (2006) Mechanisms linking obesity with cardiovascular disease. Nature $\mathbf{4 4 4}$, 875-880.

5. Donath MY \& Shoelson SE (2011) Type 2 diabetes as an inflammatory disease. Nat Rev Immunol 11, 98-107.

6. Gregor MF \& Hotamisligil GS (2011) Inflammatory mechanisms in obesity. Annu Rev Immunol 29, 415-445.
7. Calle EE (2007) Obesity and cancer. BMJ 335, 1107-1108.

8. Fabbrini E, Sullivan S \& Klein S (2010) Obesity and nonalcoholic fatty liver disease: biochemical, metabolic, and clinical implications. Hepatology 51, 679-689.

9. Pischon T, Boeing H, Hoffmann K, et al. (2008) General and abdominal adiposity and risk of death in Europe. $N$ Engl J Med 359, 2105-2120.

10. Berrington de Gonzalez A, Hartge P, Cerhan JR, et al. (2010) Body-mass index and mortality among 1.46 million white adults. $N$ Engl J Med 363, 2211-2219.

11. O'Rahilly S (2009) Human genetics illuminates the paths to metabolic disease. Nature 462, 307-314.

12. Woods SC (2009) The control of food intake: behavioral versus molecular perspectives. Cell Metab 9, 489-498.

13. Frühbeck G \& Gómez-Ambrosi J (2003) Control of body weight: a physiologic and transgenic perspective. Diabetologia 46, 143-172.

14. Takahashi N, Li F, Hua K, et al. (2007) Increased energy expenditure, dietary fat wasting, and resistance to diet-induced obesity in mice lacking renin. Cell Metab 6 , 506-512.

15. Gómez-Ambrosi J, Rodríguez A, Catalán V, et al. (2008) The bone-adipose axis in obesity and weight loss. Obes Surg 18, 1134-1143.

16. Valentino MA, Lin JE, Snook AE, et al. (2011) A uroguanylin-GUCY2C endocrine axis regulates feeding in mice. $J$ Clin Invest 121, 3578-3588.

17. Choi SJ, Yablonka-Reuveni Z, Kaiyala KJ, et al. (2011) Increased energy expenditure and leptin sensitivity account for low fat mass in myostatin-deficient mice. Am J Physiol Endocrinol Metab 300, E1031-E1037.

18. Somogyi V, Gyorffy A, Scalise TJ, et al. (2011) Endocrine factors in the hypothalamic regulation of food intake in females: a review of the physiological roles and interactions of ghrelin, leptin, thyroid hormones, oestrogen and insulin. Nutr Res Rev 24, 132-154.

19. Field BC, Chaudhri OB \& Bloom SR (2010) Bowels control brain: gut hormones and obesity. Nat Rev Endocrinol 6, 444-453.

20. Kennedy GC (1953) The role of depot fat in the hypothalamic control of food intake in the rat. Proc Royal Soc London 140B, 579-592.

21. Frühbeck G \& Gómez Ambrosi J (2001) Rationale for the existence of additional adipostatic hormones. FASEB J 15, 1996-2006.

22. Frühbeck G \& Salvador J (2004) Role of adipocytokines in metabolism and disease. Nutr Res 24, 803-826.

23. Frühbeck G, Gómez-Ambrosi J, Muruzábal FJ, et al. (2001) The adipocyte: a model for integration of endocrine and metabolic signaling in energy metabolism regulation. $\mathrm{Am}$ $J$ Physiol Endocrinol Metab 280, E827-E847.

24. Frühbeck G \& Gómez-Ambrosi J (2005) Adipose tissue. In Encyclopedia of Human Nutrition, 2nd ed., pp. 1-14 [B Caballero, L Allen and A Prentice, editors]. Oxford, UK: Elsevier Ltd.

25. Catalán V, Gómez-Ambrosi J, Rodríguez A, et al. (2009) Adipokines in the treatment of diabetes mellitus and obesity. Expert Opin Pharmacother 10, 239-254.

26. Zhang Y, Proenca R, Maffei M, et al. (1994) Positional cloning of the mouse obese gene and its human homologue. Nature 372, 425-432.

27. Morton GJ, Cummings DE, Baskin DG, et al. (2006) Central nervous system control of food intake and body weight. Nature 443, 289-295.

28. Myers MG Jr, Munzberg H, Leinninger GM, et al. (2009) The geometry of leptin action in the brain: more complicated than a simple ARC. Cell Metab 9, 117-123. 
29. Tartaglia LA, Dembski M, Weng X, et al. (1995) Identification and expression cloning of a leptin receptor, OB-R. Cell 83, 1263-1271.

30. Lee GH, Proenca R, Montez JM, et al. (1996) Abnormal splicing of the leptin receptor in diabetic mice. Nature 379, 632-635.

31. Frühbeck G, Gómez-Ambrosi J \& Martínez JA (1999) Preand postprandial expression of the leptin receptor splice variants $\mathrm{OB}-\mathrm{Ra}$ and $\mathrm{OB}-\mathrm{Rb}$ in murine peripheral tissues. Physiol Res 48, 189-195.

32. Frühbeck G, Jebb SA \& Prentice AM (1998) Leptin: physiology and pathophysiology. Clin Physiol 18, 399-419.

33. Frühbeck G \& Salvador J (2000) Relations between leptin and the regulation of glucose metabolism. Diabetologia 43, 3-12.

34. Muruzábal FJ, Frühbeck G, Gómez-Ambrosi J, et al. (2002) Immunocytochemical detection of leptin in nonmammalian vertebrate stomach. Gen Comp Endocrinol 128, 149-152.

35. Archanco M, Muruzábal FJ, Llopiz D, et al. (2003) Leptin expression in the rat ovary depends on estrous cycle. J Histochem Cytochem 51, 1269-1277.

36. Myers MG, Cowley MA \& Münzberg H (2008) Mechanisms of leptin action and leptin resistance. Annu Rev Physiol 70 , 537-556.

37. Morton GJ \& Schwartz MW (2011) Leptin and the central nervous system control of glucose metabolism. Physiol Rev 91, 389-411.

38. Gautron L \& Elmquist JK (2011) Sixteen years and counting: an update on leptin in energy balance. J Clin Invest $\mathbf{1 2 1}$, 2087-2093.

39. Gómez-Ambrosi J \& Frühbeck G (2007) Unlocking the molecular basis of obesity. Future Lipidol 2, 577-581.

40. Frühbeck G (2006) Intracellular signalling pathways activated by leptin. Biochem J 393, 7-20.

41. Lindström P (2007) The physiology of obesehyperglycemic mice [ob/ob mice]. Sci World J 7, 666-685.

42. Pelleymounter MA, Cullen MJ, Baker MB, et al. (1995) Effects of the obese gene product on body weight regulation in $o b / o b$ mice. Science 269, 540-543.

43. Halaas JL, Gajiwala KS, Maffei M, et al. (1995) Weightreducing effects of the plasma protein encoded by the obese gene. Science 269, 543-546.

44. Siegrist-Kaiser CA, Pauli V, Juge-Aubry CE, et al. (1997) Direct effects of leptin on brown and white adipose tissue. J Clin Invest 100, 2858-2864.

45. Frühbeck G, Aguado M, Gómez-Ambrosi J, et al. (1998) Lipolytic effect of in vivo leptin administration on adipocytes of lean and $o b / o b$ mice, but not $d b / d b$ mice. Biochem Biophys Res Commun 250, 99-102.

46. Gallardo N, Bonzón-Kulichenko E, Fernández-Agulloó T, et al. (2007) Tissue-specific effects of central leptin on the expression of genes involved in lipid metabolism in liver and white adipose tissue. Endocrinology $\mathbf{1 4 8}$, 5604-5610.

47. Wang MY, Lee Y \& Unger RH (1999) Novel form of lipolysis induced by leptin. J Biol Chem 274, 17541-17544.

48. Hwa JJ, Fawzi AB, Graziano MP, et al. (1997) Leptin increases energy expenditure and selectively promotes fat metabolism in $o b / o b$ mice. Am J Physiol 272, R1204-R1209.

49. Montague CT, Farooqi IS, Whitehead JP, et al. (1997) Congenital leptin deficiency is associated with severe early-onset obesity in humans. Nature 387, 903-908.

50. Strobel A, Issad T, Camoin L, et al. (1998) A leptin missense mutation associated with hypogonadism and morbid obesity. Nat Genet 18, 213-215.
51. Farooqi IS, Jebb SA, Langmack G, et al. (1999) Effects of recombinant leptin therapy in a child with congenital leptin deficiency. $N$ Engl J Med 341, 879-884.

52. Farooqi IS, Matarese G, Lord GM, et al. (2002) Beneficial effects of leptin on obesity, $\mathrm{T}$ cell hyporesponsiveness, and neuroendocrine/metabolic dysfunction of human congenital leptin deficiency. J Clin Invest 110, 1093-1103.

53. Licinio J, Caglayan S, Ozata M, et al. (2004) Phenotypic effects of leptin replacement on morbid obesity, diabetes mellitus, hypogonadism, and behavior in leptin-deficient adults. Proc Natl Acad Sci US A 101, 4531-4536.

54. Paz-Filho G, Wong ML \& Licinio J (2011) Ten years of leptin replacement therapy. Obes Rev 12, e315-e323.

55. Rosenbaum M, Goldsmith R, Bloomfield D, et al. (2005) Low-dose leptin reverses skeletal muscle, autonomic, and neuroendocrine adaptations to maintenance of reduced weight. J Clin Invest 115, 3579-3586.

56. Galgani JE, Greenway FL, Caglayan S, et al. (2010) Leptin replacement prevents weight loss-induced metabolic adaptation in congenital leptin-deficient patients. $J$ Clin Endocrinol Metab 95, 851-855.

57. Kadowaki $\mathrm{T} \&$ \& Yamauchi $\mathrm{T}$ (2005) Adiponectin and adiponectin receptors. Endocr Rev 26, 439-451.

58. Trujillo ME \& Scherer PE (2005) Adiponectin - journey from an adipocyte secretory protein to biomarker of the metabolic syndrome. J Intern Med 257, 167-175.

59. Kadowaki T, Yamauchi T, Kubota N, et al. (2006) Adiponectin and adiponectin receptors in insulin resistance, diabetes, and the metabolic syndrome. J Clin Invest 116, 1784-1792.

60. Yamauchi T, Kamon J, Ito Y, et al. (2003) Cloning of adiponectin receptors that mediate antidiabetic metabolic effects. Nature 423, 762-769.

61. Hug C, Wang J, Ahmad NS, et al. (2004) T-cadherin is a receptor for hexameric and high-molecular-weight forms of Acrp30/adiponectin. Proc Natl Acad Sci US A 101, 10308-10313.

62. Arita Y, Kihara S, Ouchi N, et al. (1999) Paradoxical decrease of an adipose-specific protein, adiponectin, in obesity. Biochem Biophys Res Commun 257, 79-83.

63. Weyer C, Funahashi T, Tanaka S, et al. (2001) Hypoadiponectinemia in obesity and type 2 diabetes: close association with insulin resistance and hyperinsulinemia. J Clin Endocrinol Metab 86, 1930-1935.

64. Yang WS, Lee WJ, Funahashi T, et al. (2001) Weight reduction increases plasma levels of an adipose-derived anti-inflammatory protein, adiponectin. J Clin Endocrinol Metab 86, 3815-3819.

65. Hotta K, Funahashi T, Arita Y, et al. (2000) Plasma concentrations of a novel, adipose-specific protein, adiponectin, in type 2 diabetic patients. Arterioscler Thromb Vasc Biol 20, 1595-1599.

66. Spranger J, Kroke A, Mohlig M, et al. (2003) Adiponectin and protection against type 2 diabetes mellitus. Lancet 361, 226-228.

67. Ouchi N, Kihara S, Arita Y, et al. (1999) Novel modulator for endothelial adhesion molecules: adipocyte-derived plasma protein adiponectin. Circulation 100, 2473-2476.

68. Berg AH, Combs TP, Du X, et al. (2001) The adipocytesecreted protein Acrp30 enhances hepatic insulin action. Nat Med 7, 947-953.

69. Combs TP, Wagner JA, Berger J, et al. (2002) Induction of adipocyte complement-related protein of 30 kilodaltons by PPAR $\gamma$ agonists: a potential mechanism of insulin sensitization. Endocrinology 143, 998-1007.

70. Matsuzawa Y, Funahashi T, Kihara S, et al. (2004) Adiponectin and metabolic syndrome. Arterioscler Thromb Vasc Biol 24, 29-33. 
71. Maeda N, Shimomura I, Kishida K, et al. (2002) Diet-induced insulin resistance in mice lacking adiponectin/ACRP30. Nat Med 8, 731-737.

72. Kubota N, Terauchi Y, Yamauchi T, et al. (2002) Disruption of adiponectin causes insulin resistance and neointimal formation. J Biol Chem 277, 25863-25866.

73. Yamauchi T, Nio Y, Maki T, et al. (2007) Targeted disruption of AdipoR1 and AdipoR2 causes abrogation of adiponectin binding and metabolic actions. Nat Med 13, 332-339.

74. Dridi S \& Taouis M (2009) Adiponectin and energy homeostasis: consensus and controversy. J Nutr Biochem 20, 831-839.

75. Qi Y, Takahashi N, Hileman SM, et al. (2004) Adiponectin acts in the brain to decrease body weight. Nat Med 10, 524-529.

76. Park S, Kim DS, Kwon DY, et al. (2011) Long-term central infusion of adiponectin improves energy and glucose homeostasis by decreasing fat storage and suppressing hepatic gluconeogenesis without changing food intake. J Neuroendocrinol 23, 687-698.

77. Kubota N, Yano W, Kubota T, et al. (2007) Adiponectin stimulates AMP-activated protein kinase in the hypothalamus and increases food intake. Cell Metab 6, 55-68.

78. Frühbeck G, Alonso R, Marzo F, et al. (1995) A modified method for the indirect quantitative analysis of phytate in foodstuffs. Anal Biochem 225, 206-212.

79. Steppan CM, Bailey ST, Bhat S, et al. (2001) The hormone resistin links obesity to diabetes. Nature $\mathbf{4 0 9}$, 307-312.

80. McTernan PG, Kusminski CM \& Kumar S (2006) Resistin. Curr Opin Lipidol 17, 170-175.

81. Gómez-Ambrosi J \& Frühbeck G (2005) Evidence for the involvement of resistin in inflammation and cardiovascular disease. Curr Diabetes Rev 1, 227-234.

82. Rangwala SM, Rich AS, Rhoades B, et al. (2004) Abnormal glucose homeostasis due to chronic hyperresistinemia. Diabetes 53, 1937-1941.

83. Satoh H, Nguyen MT, Miles PD, et al. (2004) Adenovirusmediated chronic 'hyper-resistinemia' leads to in vivo insulin resistance in normal rats. J Clin Invest 114, 224-231.

84. Qi Y, Nie Z, Lee Y-S, et al. (2006) Loss of resistin improves glucose homeostasis in leptin deficiency. Diabetes $\mathbf{5 5}$, 3083-3090.

85. Kusminski CM, McTernan PG \& Kumar S (2005) Role of resistin in obesity, insulin resistance and type II diabetes. Clin Sci 109, 243-256.

86. Schwartz DR \& Lazar MA (2011) Human resistin: found in translation from mouse to man. Trends Endocrinol Metab 22, 259-265.

87. Azuma K, Katsukawa F, Oguchi S, et al. (2003) Correlation between serum resistin level and adiposity in obese individuals. Obes Res 11, 997-1001.

88. Degawa-Yamauchi M, Bovenkerk JE, Juliar BE, et al. (2003) Serum resistin (FIZZ3) protein is increased in obese humans. J Clin Endocrinol Metab 88, 5452-5455.

89. Silha JV, Krsek M, Skrha JV, et al. (2003) Plasma resistin, adiponectin and leptin levels in lean and obese subjects: correlations with insulin resistance. Eur J Endocrinol 149, $331-335$.

90. Lee JH, Chan JL, Yiannakouris N, et al. (2003) Circulating resistin levels are not associated with obesity or insulin resistance in humans and are not regulated by fasting or leptin administration: cross-sectional and interventional studies in normal, insulin-resistant, and diabetic subjects. $J$ Clin Endocrinol Metab 88, 4848-4856.

91. Heilbronn LK, Rood J, Janderova L, et al. (2004) Relationship between serum resistin concentrations and insulin resistance in nonobese, obese, and obese diabetic subjects J Clin Endocrinol Metab 89, 1844-1848.

92. Fehmann HC \& Heyn J (2002) Plasma resistin levels in patients with type 1 and type 2 diabetes mellitus and in healthy controls. Horm Metab Res 34, 671-673.

93. Chen MP, Chung FM, Chang DM, et al. (2006) Elevated plasma level of visfatin/pre-B cell colony-enhancing factor in patients with type 2 diabetes mellitus. J Clin Endocrinol Metab 91, 295-299.

94. Heidemann C, Sun Q, van Dam RM, et al. (2008) Total and high-molecular-weight adiponectin and resistin in relation to the risk for type 2 diabetes in women. Ann Intern Med 149, 307-316.

95. Utzschneider KM, Carr DB, Tong J, et al. (2005) Resistin is not associated with insulin sensitivity or the metabolic syndrome in humans. Diabetologia 48, 2330-2333.

96. Gómez-Ambrosi J \& Frühbeck G (2001) Do resistin and resistin-like molecules also link obesity to inflammatory diseases? Ann Intern Med 135, 306-307.

97. Bokarewa M, Nagaev I, Dahlberg L, et al. (2005) Resistin, an adipokine with potent proinflammatory properties. J Immunol 174, 5789-5795.

98. Silswal N, Singh AK, Aruna B, et al. (2005) Human resistin stimulates the pro-inflammatory cytokines TNF- $\alpha$ and IL-12 in macrophages by NF-кB-dependent pathway. Biochem Biophys Res Commun 334, 1092-1101.

99. Kaser S, Kaser A, Sandhofer A, et al. (2003) Resistin messenger-RNA expression is increased by proinflammatory cytokines in vitro. Biochem Biophys Res Commun 309, 286-290.

100. Lehrke M, Reilly MP, Millington SC, et al. (2004) An inflammatory cascade leading to hyperresistinemia in humans. PLoS Med 1, e45.

101. Reilly MP, Lehrke M, Wolfe ML, et al. (2005) Resistin is an inflammatory marker of atherosclerosis in humans. Circulation 111, 932-939.

102. Kusminski CM, da Silva NF, Creely SJ, et al. (2007) The in vitro effects of resistin on the innate immune signaling pathway in isolated human subcutaneous adipocytes. J Clin Endocrinol Metab 92, 270-276.

103. Tovar S, Nogueiras R, Tung LY, et al. (2005) Central administration of resistin promotes short-term satiety in rats. Eur J Endocrinol 153, R1-R5.

104. Park S, Hong SM, Sung SR, et al. (2008) Long-term effects of central leptin and resistin on body weight, insulin resistance, and $\beta$-cell function and mass by the modulation of hypothalamic leptin and insulin signaling. Endocrinology 149, 445-454.

105. Cifani C, Durocher Y, Pathak A, et al. (2009) Possible common central pathway for resistin and insulin in regulating food intake. Acta Physiol 196, 395-400.

106. Vázquez MJ, González CR, Varela L, et al. (2008) Central resistin regulates hypothalamic and peripheral lipid metabolism in a nutritional-dependent fashion. Endocrinology 149, 4534-4543.

107. Singhal NS, Lazar MA \& Ahima RS (2007) Central resistin induces hepatic insulin resistance via neuropeptide Y. J Neurosci 27, 12924-12932.

108. Kim KH, Lee K, Moon YS, et al. (2001) A cysteine-rich adipose tissue-specific secretory factor inhibits adipocyte differentiation. J Biol Chem 276, 11252-11256.

109. Nogueiras R, Novelle MG, Vazquez MJ, et al. (2010) Resistin: regulation of food intake, glucose homeostasis and lipid metabolism. Endocr Dev 17, 175-184.

110. Maslowska M, Sniderman AD, Germinario R, et al. (1997) ASP stimulates glucose transport in cultured human adipocytes. Int J Obes Relat Metab Disord 21, 261-266. 
111. Cianflone K, Xia Z \& Chen LY (2003) Critical review of acylation-stimulating protein physiology in humans and rodents. Biochim Biophys Acta 1609, 127-143.

112. Yasruel Z, Cianflone K, Sniderman AD, et al. (1991) Effect of acylation stimulating protein on the triacylglycerol synthetic pathway of human adipose tissue. Lipids 26, 495-499.

113. Germinario R, Sniderman AD, Manuel S, et al. (1993) Coordinate regulation of triacylglycerol synthesis and glucose transport by acylation-stimulating protein. Metabolism $\mathbf{4 2}$, 574-580.

114. Saleh J, Al-Wardy N, Farhan H, et al. (2011) Acylation stimulating protein: a female lipogenic factor? Obes Rev $\mathbf{1 2}$ $440-448$.

115. Xia Z, Stanhope KL, Digitale E, et al. (2004) Acylation-stimulating protein (ASP)/complement C3adesArg deficiency results in increased energy expenditure in mice. $J$ Biol Chem 279, 4051-4057.

116. Xia Z, Sniderman AD \& Cianflone K (2002) Acylation-stimulating protein (ASP) deficiency induces obesity resistance and increased energy expenditure in $\mathrm{ob} / \mathrm{ob}$ mice. $J$ Biol Chem 277, 45874-45879.

117. Paglialunga S, Schrauwen P, Roy C, et al. (2007) Reduced adipose tissue triglyceride synthesis and increased muscle fatty acid oxidation in C5L2 knockout mice. $J$ Endocrinol 194, 293-304.

118. Paglialunga S, Fisette A, Munkonda M, et al. (2010) The effects of acylation stimulating protein supplementation VS antibody neutralization on energy expenditure in wildtype mice. BMC Physiol 10, 4.

119. Roy C, Roy MC, Gauvreau D, et al. (2011) Acute injection of ASP in the third ventricle inhibits food intake and locomotor activity in rats. Am J Physiol Endocrinol Metab 301, E232-E241.

120. Rodríguez A, Catalán V, Gómez-Ambrosi J, et al. (2007) Visceral and subcutaneous adiposity: are both potential therapeutic targets for tackling the metabolic syndrome? Curr Pharm Des 13, 2169-2175.

121. Cawthorn WP, Heyd F, Hegyi K, et al. (2007) Tumour necrosis factor- $\alpha$ inhibits adipogenesis via a $\beta$-catenin/ TCF4(TCF7L2)-dependent pathway. Cell Death Differ $\mathbf{1 4}$ $1361-1373$

122. Cawthorn WP \& Sethi JK (2008) TNF- $\alpha$ and adipocyte biology. FEBS Lett 582, 117-131.

123. Hotamisligil GS (2006) Inflammation and metabolic disorders. Nature 444, 860-867.

124. Uysal KT, Wiesbrock SM, Marino MW, et al. (1997) Protection from obesity-induced insulin resistance in mice lacking TNF- $\alpha$ function. Nature 389, 610-614.

125. Tisdale MJ (2009) Mechanisms of cancer cachexia. Physiol Rev 89, 381-410.

126. de Kloet AD, Pacheco-Lopez G, Langhans W, et al. (2011) The effect of TNF $\alpha$ on food intake and central insulin sensitivity in rats. Physiol Behav 103, 17-20.

127. Amaral ME, Barbuio R, Milanski M, et al. (2006) Tumor necrosis factor- $\alpha$ activates signal transduction in hypothalamus and modulates the expression of pro-inflammatory proteins and orexigenic/anorexigenic neurotransmitters. J Neurochem 98, 203-212.

128. Frühbeck G, Sesma P \& Burrell MA (2009) PRDM16: the interconvertible adipo-myocyte switch. Trends Cell Biol 19, 141-146

129. Frühbeck G, Becerril S, Sáinz N, et al. (2009) BAT: a new target for human obesity? Trends Pharmacol Sci 30 387-396.

130. Cypess AM, Lehman S, Williams G, et al. (2009) Identification and importance of brown adipose tissue in adult humans. N Engl J Med 360, 1509-1517.
131. Masaki T, Yoshimatsu H, Chiba S, et al. (1999) Tumor necrosis factor- $\alpha$ regulates in vivo expression of the rat UCP family differentially. Biochim Biophys Acta 1436, 585-592.

132. Valladares A, Roncero C, Benito M, et al. (2001) TNF- $\alpha$ inhibits UCP-1 expression in brown adipocytes via ERKs. Opposite effect of p38MAPK. FEBS Lett 493, 6-11.

133. Romanatto T, Roman EA, Arruda AP, et al. (2009) Deletion of tumor necrosis factor- $\alpha$ receptor 1 (TNFR1) protects against diet-induced obesity by means of increased thermogenesis. J Biol Chem 284, 36213-36222.

134. Bastard JP, Maachi M, Van Nhieu JT, et al. (2002) Adipose tissue IL-6 content correlates with resistance to insulin activation of glucose uptake both in vivo and in vitro. J Clin Endocrinol Metab 87, 2084-2089.

135. Tilg $\mathrm{H} \&$ Moschen AR (2008) Inflammatory mechanisms in the regulation of insulin resistance. Mol Med 14, 222-231.

136. Wallenius V, Wallenius K, Ahren B, et al. (2002) Interleukin6-deficient mice develop mature-onset obesity. Nat Med $\mathbf{8}$, 75-79.

137. Carey AL, Steinberg GR, Macaulay SL, et al. (2006) Interleukin-6 increases insulin-stimulated glucose disposal in humans and glucose uptake and fatty acid oxidation in vitro via AMP-activated protein kinase. Diabetes 55, $2688-2697$.

138. Wallenius K, Wallenius V, Sunter D, et al. (2002) Intracerebroventricular interleukin- 6 treatment decreases body fat in rats. Biochem Biophys Res Commun 293, 560-565.

139. Chida D, Osaka T, Hashimoto O, et al. (2006) Combined interleukin-6 and interleukin-1 deficiency causes obesity in young mice. Diabetes 55, 971-977.

140. Benrick A, Schele E, Pinnock SB, et al. (2009) Interleukin-6 gene knockout influences energy balance regulating peptides in the hypothalamic paraventricular and supraoptic nuclei. J Neuroendocrinol 21, 620-628.

141. Stouthard JM, Romijn JA, Van der Poll T, et al. (1995) Endocrinologic and metabolic effects of interleukin-6 in humans. Am J Physiol 268, E813-E819.

142. Tsigos C, Papanicolaou DA, Defensor R, et al. (1997) Dose effects of recombinant human interleukin- 6 on pituitary hormone secretion and energy expenditure. Neuroendocrinology 66, 54-62.

143. Kubaszek A, Pihlajamaki J, Punnonen K, et al. (2003) The C-174G promoter polymorphism of the IL- 6 gene affects energy expenditure and insulin sensitivity. Diabetes 52, $558-561$.

144. Hoene M \& Weigert C (2008) The role of interleukin-6 in insulin resistance, body fat distribution and energy balance. Obes Rev 9, 20-29.

145. Ouchi N, Parker JL, Lugus JJ, et al. (2011) Adipokines in inflammation and metabolic disease. Nat Rev Immunol 11, 85-97.

146. Fukuhara A, Matsuda M, Nishizawa M, et al. (2005) Visfatin: a protein secreted by visceral fat that mimics the effects of insulin. Science 307, 426-430.

147. Fukuhara A, Matsuda M, Nishizawa M, et al. (2007) Visfatin: a protein secreted by visceral fat that mimics the effects of insulin: retraction. Science 318, 565 .

148. Berndt J, Klöting N, Kralisch S, et al. (2005) Plasma visfatin concentrations and fat depot-specific mRNA expression in humans. Diabetes 54, 2911-2916.

149. Catalán V, Gómez-Ambrosi J, Rodríguez A, et al. (2011) Association of increased visfatin/PBEF/NAMPT circulating concentrations and gene expression levels in peripheral blood cells with lipid metabolism and fatty liver in human morbid obesity. Nutr Metab Cardiovasc Dis 21, $245-253$. 
150. Revollo JR, Korner A, Mills KF, et al. (2007) Nampt/PBEF/ visfatin regulates insulin secretion in $\beta$ cells as a systemic NAD biosynthetic enzyme. Cell Metab 6, 363-375.

151. Moschen AR, Kaser A, Enrich B, et al. (2007) Visfatin, an adipocytokine with proinflammatory and immunomodulating properties. J Immunol 178, 1748-1758.

152. Park BS, Jin SH, Park JJ, et al. (2011) Visfatin induces sickness responses in the brain. PLOS ONE 6, e15981.

153. Arner P (2006) Editorial: visfatin - a true or false trail to type 2 diabetes mellitus. J Clin Endocrinol Metab 91, $28-30$.

154. Hida K, Wada J, Eguchi J, et al. (2005) Visceral adipose tissue-derived serine protease inhibitor: a unique insulinsensitizing adipocytokine in obesity. Proc Natl Acad Sci U S A 102, 10610-10615.

155. Klöting N, Berndt J, Kralisch S, et al. (2006) Vaspin gene expression in human adipose tissue: association with obesity and type 2 diabetes. Biochem Biophys Res Commun 339, 430-436.

156. Youn BS, Klöting N, Kratzsch J, et al. (2008) Serum vaspin concentrations in human obesity and type 2 diabetes. Diabetes 57, 372-377.

157. Zvonic S, Lefevre M, Kilroy G, et al. (2007) Secretome of primary cultures of human adipose-derived stem cells: modulation of serpins by adipogenesis. Mol Cell Proteomics 6, $18-28$.

158. González CR, Caminos JE, Vázquez MJ, et al. (2009) Regulation of visceral adipose tissue-derived serine protease inhibitor by nutritional status, metformin, gender and pituitary factors in rat white adipose tissue. J Physiol 587, 3741-3750.

159. Jeong E, Youn BS, Kim DW, et al. (2010) Circadian rhythm of serum vaspin in healthy male volunteers: relation to meals. J Clin Endocrinol Metab 95, 1869-1875.

160. Klöting N, Kovacs P, Kern M, et al. (2011) Central vaspin administration acutely reduces food intake and has sustained blood glucose-lowering effects. Diabetologia $\mathbf{5 4}$, 1819-1823.

161. Brunetti L, Di Nisio C, Recinella L, et al. (2011) Effects of vaspin, chemerin and omentin-1 on feeding behavior and hypothalamic peptide gene expression in the rat. Peptides 32, 1866-1871.

162. Ernst MC \& Sinal CJ (2010) Chemerin: at the crossroads of inflammation and obesity. Trends Endocrinol Metab 21, 660-667.

163. Bozaoglu K, Bolton K, McMillan J, et al. (2007) Chemerin is a novel adipokine associated with obesity and metabolic syndrome. Endocrinology 148, 4687-4694.

164. Goralski KB, McCarthy TC, Hanniman EA, et al. (2007) Chemerin: a novel adipokine that regulates adipogenesis and adipocyte metabolism. J Biol Chem 282, 28175-28188.

165. Hart R \& Greaves DR (2010) Chemerin contributes to inflammation by promoting macrophage adhesion to VCAM-1 and fibronectin through clustering of VLA-4 and VLA-5. J Immunol 185, 3728-3739.

166. Sell H, Divoux A, Poitou C, et al. (2010) Chemerin correlates with markers for fatty liver in morbidly obese patients and strongly decreases after weight loss induced by bariatric surgery. J Clin Endocrinol Metab 95, 2892-2896.

167. Catalán V, Gómez-Ambrosi J, Rodríguez A, et al. (2011) Increased levels of chemerin and its receptor, chemokinelike receptor- 1 , in obesity are related to inflammation: tumor necrosis factor- $\alpha$ stimulates mRNA levels of chemerin in visceral adipocytes from obese patients. Surg Obes Relat Dis (epublication ahead of print version 10 November 2011).
168. Schaffler A, Neumeier M, Herfarth H, et al. (2005) Genomic structure of human omentin, a new adipocytokine expressed in omental adipose tissue. Biochim Biophys Acta 1732, 96-102.

169. Yang RZ, Lee MJ, Hu H, et al. (2006) Identification of omentin as a novel depot-specific adipokine in human adipose tissue: possible role in modulating insulin action. Am J Physiol Endocrinol Metab 290, E1253-E1261.

170. de Souza Batista CM, Yang RZ, Lee MJ, et al. (2007) Omentin plasma levels and gene expression are decreased in obesity. Diabetes 56, 1655-1661.

171. Tan BK, Adya R \& Randeva HS (2010) Omentin: a novel link between inflammation, diabesity, and cardiovascular disease. Trends Cardiovasc Med 20, 143-148.

172. Moreno-Navarrete JM, Catalán V, Ortega F, et al. (2010) Circulating omentin concentration increases after weight loss. Nutr Metab 7, 27.

173. Yvan-Charvet L \& Quignard-Boulange A (2011) Role of adipose tissue renin-angiotensin system in metabolic and inflammatory diseases associated with obesity. Kidney Int 79, 162-168.

174. Kalupahana NS \& Moustaid-Moussa N (2012) The reninangiotensin system: a link between obesity, inflammation and insulin resistance. Obes Rev 13, 136-149.

175. Katovich MJ \& Pachori A (2000) Effects of inhibition of the renin-angiotensin system on the cardiovascular actions of insulin. Diabetes Obes Metab 2, 3-14.

176. Luther JM \& Brown NJ (2011) The renin-angiotensinaldosterone system and glucose homeostasis. Trends Pharmacol Sci 32, 734-739.

177. Engeli S, Schling P, Gorzelniak K, et al. (2003) The adipose-tissue renin-angiotensin-aldosterone system: role in the metabolic syndrome? Int J Biochem Cell Biol 35, $807-825$.

178. Massiera F, Seydoux J, Geloen A, et al. (2001) Angiotensinogen-deficient mice exhibit impairment of diet-induced weight gain with alteration in adipose tissue development and increased locomotor activity. Endocrinology 142, $5220-5225$.

179. Kouyama R, Suganami T, Nishida J, et al. (2005) Attenuation of diet-induced weight gain and adiposity through increased energy expenditure in mice lacking angiotensin II type 1a receptor. Endocrinology 146, 3481-3489.

180. Yvan-Charvet L, Even P, Bloch-Faure M, et al. (2005) Deletion of the angiotensin type 2 receptor (AT2R) reduces adipose cell size and protects from diet-induced obesity and insulin resistance. Diabetes 54, 991-999.

181. Jayasooriya AP, Mathai ML, Walker LL, et al. (2008) Mice lacking angiotensin-converting enzyme have increased energy expenditure, with reduced fat mass and improved glucose clearance. Proc Natl Acad Sci U S A 105, 6531-6536.

182. Brink M, Wellen J \& Delafontaine P (1996) Angiotensin II causes weight loss and decreases circulating insulin-like growth factor $\mathrm{I}$ in rats through a pressor-independent mechanism. J Clin Invest 97, 2509-2516.

183. Cassis L, Helton M, English V, et al. (2002) Angiotensin II regulates oxygen consumption. Am J Physiol Regul Integr Comp Physiol 282, R445-R453.

184. de Kloet AD, Krause EG, Kim DH, et al. (2009) The effect of angiotensin-converting enzyme inhibition using captopril on energy balance and glucose homeostasis. Endocrinology 150, 4114-4123.

185. Porter JP \& Potratz KR (2004) Effect of intracerebroventricular angiotensin II on body weight and food intake in adult rats. Am J Physiol Regul Integr Comp Physiol 287, R422-R428. 
186. de Kloet AD, Krause EG, Scott KA, et al. (2011) Central angiotensin II has catabolic action at white and brown adipose tissue. Am J Physiol Endocrinol Metab 301, E1081-E1091.

187. de Kloet AD, Krause EG \& Woods SC (2010) The renin angiotensin system and the metabolic syndrome. Physiol Behav 100, 525-534.

188. Tchernof A \& Despres JP (2000) Sex steroid hormones, sex hormone-binding globulin, and obesity in men and women. Horm Metab Res 32, 526-536.

189. Mayes JS \& Watson GH (2004) Direct effects of sex steroid hormones on adipose tissues and obesity. Obes Rev 5, 197-216.

190. Brown LM, Gent L, Davis K, et al. (2010) Metabolic impact of sex hormones on obesity. Brain Res 1350, 77-85.

191. Mauvais-Jarvis F (2011) Estrogen and androgen receptors: regulators of fuel homeostasis and emerging targets for diabetes and obesity. Trends Endocrinol Metab 22, 24-33.

192. Mattiasson I, Rendell M, Tornquist C, et al. (2002) Effects of estrogen replacement therapy on abdominal fat compartments as related to glucose and lipid metabolism in early postmenopausal women. Horm Metab Res 34, 583-588.

193. Tsai EC, Boyko EJ, Leonetti DL, et al. (2000) Low serum testosterone level as a predictor of increased visceral fat in Japanese-American men. Int J Obes Relat Metab Disord 24, 485-491.

194. Kupelian V, Page ST, Araujo AB, et al. (2006) Low sex hormone-binding globulin, total testosterone, and symptomatic androgen deficiency are associated with development of the metabolic syndrome in nonobese men. J Clin Endocrinol Metab 91, 843-850

195. Marin P, Holmang S, Jonsson L, et al. (1992) The effects of testosterone treatment on body composition and metabolism in middle-aged obese men. Int J Obes Relat Metab Disord 16, 991-997.

196. Eckel LA (2011) The ovarian hormone estradiol plays a crucial role in the control of food intake in females. Physiol Behav 104, 517-524.

197. Heine PA, Taylor JA, Iwamoto GA, et al. (2000) Increased adipose tissue in male and female estrogen receptor- $\alpha$ knockout mice. Proc Natl Acad Sci U S A 97, 12729-12734.

198. Musatov S, Chen W, Pfaff DW, et al. (2007) Silencing of estrogen receptor $\alpha$ in the ventromedial nucleus of hypothalamus leads to metabolic syndrome. Proc Natl Acad Sci US A 104, 2501-2506.

199. Ropero AB, Alonso-Magdalena P, Quesada I, et al. (2008) The role of estrogen receptors in the control of energy and glucose homeostasis. Steroids 73, 874-879.

200. Fan W, Yanase T, Nomura M, et al. (2005) Androgen receptor null male mice develop late-onset obesity caused by decreased energy expenditure and lipolytic activity but show normal insulin sensitivity with high adiponectin secretion. Diabetes 54, 1000-1008.

201. Xu Y, Nedungadi TP, Zhu L, et al. (2011) Distinct hypothalamic neurons mediate estrogenic effects on energy homeostasis and reproduction. Cell Metab 14, 453-465.

202. Plum L, Belgardt BF \& Brüning JC (2006) Central insulin action in energy and glucose homeostasis. J Clin Invest 116, 1761-1766.

203. Woods SC, Lotter EC, McKay LD, et al. (1979) Chronic intracerebroventricular infusion of insulin reduces food intake and body weight of baboons. Nature 282, 503-505.

204. Brüning JC, Gautam D, Burks DJ, et al. (2000) Role of brain insulin receptor in control of body weight and reproduction. Science 289, 2122-2125.

205. Schwartz MW, Woods SC, Porte D Jr, et al. (2000) Central nervous system control of food intake. Nature $\mathbf{4 0 4}$, 661-671.
206. Könner AC, Klöckener T \& Brüning JC (2009) Control of energy homeostasis by insulin and leptin: targeting the arcuate nucleus and beyond. Physiol Behav 97, 632-638.

207. Rothwell NJ \& Stock MJ (1988) Insulin and thermogenesis. Int J Obes 12, 98-103.

208. Menéndez JA \& Atrens DM (1989) Insulin increases energy expenditure and respiratory quotient in the rat. Pharmacol Biochem Behav 34, 765-768.

209. Dulloo AG \& Girardier L (1989) Energy expenditure and diet-induced thermogenesis in presence and absence of hyperphagia induced by insulin. Am J Physiol 257, R717-R725.

210. Jiang G \& Zhang BB (2003) Glucagon and regulation of glucose metabolism. Am J Physiol Endocrinol Metab 284, E671-E678.

211. Gómez-Ambrosi J, Catalan V \& Frühbeck G (2009) The adipo-hepato-insular axis in glucose homeostasis. In Peptides in Energy Balance and Obesity, pp. 163-193 [G Frühbeck, editor]. Wallingford: CABI Publishing.

212. Kalkhoff RK, Gossain VV \& Matute ML (1973) Plasma glucagon in obesity. Response to arginine, glucose and protein administration. $N$ Engl J Med 289, 465-467.

213. Starke AA, Erhardt G, Berger M, et al. (1984) Elevated pancreatic glucagon in obesity. Diabetes 33, 277-280.

214. Koeslag JH, Saunders PT \& Terblanche E (2003) A reappraisal of the blood glucose homeostat which comprehensively explains the type 2 diabetes mellitus-syndrome X complex. J Physiol 549, 333-346.

215. Penick SB \& Hinkle LE Jr (1961) Depression of food intake induced in healthy subjects by glucagon. N Engl J Med $\mathbf{2 6 4}$, 893-897.

216. Geary N, Langhans W \& Scharrer E (1981) Metabolic concomitants of glucagon-induced suppression of feeding in the rat. Am J Physiol 241, R330-R335.

217. Habegger KM, Heppner KM, Geary N, et al. (2010) The metabolic actions of glucagon revisited. Nat Rev Endocrinol 6, 689-697.

218. Schulman JL, Carleton JL, Whitney G, et al. (1957) Effect of glucagon on food intake and body weight in man. $J A p p l$ Physiol 11, 419-421.

219. Billington CJ, Briggs JE, Link JG, et al. (1991) Glucagon in physiological concentrations stimulates brown fat thermogenesis in vivo. Am J Physiol 261, R501-R507.

220. Davidson IW, Salter JM \& Best CH (1957) Calorigenic action of glucagon. Nature 180, 1124

221. Gelling RW, Du XQ, Dichmann DS, et al. (2003) Lower blood glucose, hyperglucagonemia, and pancreatic $\alpha$ cell hyperplasia in glucagon receptor knockout mice. Proc Natl Acad Sci U S A 100, 1438-1443.

222. Lou PH, Gustavsson N, Wang Y, et al. (2011) Increased lipolysis and energy expenditure in a mouse model with severely impaired glucagon secretion. PLOS ONE 6, e26671.

223. Vuguin PM \& Charron MJ (2011) Novel insight into glucagon receptor action: lessons from knockout and transgenic mouse models. Diabetes Obes Metab 13, Suppl. 1, 144-150.

224. Schwartz TW, Holst JJ, Fahrenkrug J, et al. (1978) Vagal, cholinergic regulation of pancreatic polypeptide secretion. J Clin Invest 61, 781-789.

225. Jorde R \& Burhol PG (1984) Fasting and postprandial plasma pancreatic polypeptide (PP) levels in obesity. Int J Obes 8, 393-397.

226. Pieramico O, Malfertheiner $P$, Nelson DK, et al. (1990) Interdigestive cycling and post-prandial release of pancreatic polypeptide in severe obesity. Int J Obes 14, 1005-1011.

227. Lassmann V, Vague P, Vialettes B, et al. (1980) Low plasma levels of pancreatic polypeptide in obesity. Diabetes 29, $428-430$. 
228. Holst JJ, Schwartz TW, Lovgreen NA, et al. (1983) Diurnal profile of pancreatic polypeptide, pancreatic glucagon, gut glucagon and insulin in human morbid obesity. Int $J$ Obes 7, 529-538.

229. Asakawa A, Inui A, Yuzuriha H, et al. (2003) Characterization of the effects of pancreatic polypeptide in the regulation of energy balance. Gastroenterology 124, 1325-1336.

230. Ueno N, Inui A, Iwamoto M, et al. (1999) Decreased food intake and body weight in pancreatic polypeptide-overexpressing mice. Gastroenterology 117, 1427-1432.

231. Batterham RL, Le Roux CW, Cohen MA, et al. (2003) Pancreatic polypeptide reduces appetite and food intake in humans. J Clin Endocrinol Metab 88, 3989-3992.

232. Schmidt PT, Näslund E, Grybäck P, et al. (2005) A role for pancreatic polypeptide in the regulation of gastric emptying and short-term metabolic control. J Clin Endocrinol Metab 90, 5241-5246.

233. Cooper GJ, Willis AC, Clark A, et al. (1987) Purification and characterization of a peptide from amyloid-rich pancreases of type 2 diabetic patients. Proc Natl Acad Sci U S A $\mathbf{8 4}$, 8628-8632.

234. Cummings DE \& Overduin J (2007) Gastrointestinal regulation of food intake. J Clin Invest 117, 13-23.

235. Lutz TA (2010) The role of amylin in the control of energy homeostasis. Am J Physiol Regul Integr Comp Physiol 298, R1475-R1484.

236. Boyle CN \& Lutz TA (2011) Amylinergic control of food intake in lean and obese rodents. Physiol Behav 105, 129-137.

237. Trevaskis JL, Parkes DG \& Roth JD (2010) Insights into amylin-leptin synergy. Trends Endocrinol Metab 21, 473-479.

238. Aronne L, Fujioka K, Aroda V, et al. (2007) Progressive reduction in body weight after treatment with the amylin analog pramlintide in obese subjects: a phase 2 , randomized, placebo-controlled, dose-escalation study. J Clin Endocrinol Metab 92, 2977-2983.

239. Roth JD, Roland BL, Cole RL, et al. (2008) Leptin responsiveness restored by amylin agonism in diet-induced obesity: evidence from nonclinical and clinical studies. Proc Natl Acad Sci U S A 105, 7257-7562.

240. Roth JD, Hughes H, Kendall E, et al. (2006) Antiobesity effects of the $\beta$-cell hormone amylin in diet-induced obese rats: effects on food intake, body weight, composition, energy expenditure, and gene expression. Endocrinology 147, 5855-5864.

241. Mack C, Wilson J, Athanacio J, et al. (2007) Pharmacological actions of the peptide hormone amylin in the long-term regulation of food intake, food preference, and body weight. Am J Physiol Regul Integr Comp Physiol 293, R1855-R1863.

242. Osaka T, Tsukamoto A, Koyama Y, et al. (2008) Central and peripheral administration of amylin induces energy expenditure in anesthetized rats. Peptides 29, 1028-1035.

243. Rushing PA, Hagan MM, Seeley RJ, et al. (2000) Amylin: a novel action in the brain to reduce body weight. Endocrinology 141, 850-853.

244. Murphy KG, Dhillo WS \& Bloom SR (2006) Gut peptides in the regulation of food intake and energy homeostasis. Endocr Rev 27, 719-727.

245. Badman MK \& Flier JS (2005) The gut and energy balance: visceral allies in the obesity wars. Science 307, 1909-1914.

246. Kojima M \& Kangawa K (2005) Ghrelin: structure and function. Physiol Rev 85, 495-522.

247. Murphy KG \& Bloom SR (2006) Gut hormones and the regulation of energy homeostasis. Nature 444, 854-859.

248. Wren AM \& Bloom SR (2007) Gut hormones and appetite control. Gastroenterology 132, 2116-2130.
249. Kojima M, Hosoda H, Date Y, et al. (1999) Ghrelin is a growth-hormone-releasing acylated peptide from stomach. Nature 402, 656-660.

250. Nakazato M, Murakami N, Date Y, et al. (2001) A role for ghrelin in the central regulation of feeding. Nature $\mathbf{4 0 9}$ 194-198.

251. Tschöp M, Smiley DL \& Heiman ML (2000) Ghrelin induces adiposity in rodents. Nature 407, 908-913.

252. Asakawa A, Inui A, Kaga T, et al. (2001) Ghrelin is an appetite-stimulatory signal from stomach with structural resemblance to motilin. Gastroenterology 120, 337-345.

253. Wren AM, Seal LJ, Cohen MA, et al. (2001) Ghrelin enhances appetite and increases food intake in humans. $J$ Clin Endocrinol Metab 86, 5992.

254. Rodríguez A, Gómez-Ambrosi J, Catalán V, et al. (2009) Acylated and desacyl ghrelin stimulate lipid accumulation in human visceral adipocytes. Int J Obes 33, 541-552.

255. Cummings DE, Purnell JQ, Frayo RS, et al. (2001) A preprandial rise in plasma ghrelin levels suggests a role in meal initiation in humans. Diabetes 50, 1714-1749.

256. Tschöp M, Weyer C, Tataranni PA, et al. (2001) Circulating ghrelin levels are decreased in human obesity. Diabetes 50, 707-709

257. Cummings DE, Weigle DS, Frayo RS, et al. (2002) Plasma ghrelin levels after diet-induced weight loss or gastric bypass surgery. $N$ Engl J Med 346, 1623-1630.

258. Frühbeck G, Diez Caballero A \& Gil MJ (2004) Fundus functionality and ghrelin concentrations after bariatric surgery. $N$ Engl J Med 350, 308-309.

259. Frühbeck G, Diez-Caballero A, Gil MJ, et al. (2004) The decrease in plasma ghrelin concentrations following bariatric surgery depends on the functional integrity of the fundus. Obes Surg 14, 606-612.

260. Holdstock C, Engström BE, Öhrvall M, et al. (2003) Ghrelin and adipose tissue regulatory peptides: effect of gastric bypass surgery in obese humans. J Clin Endocrinol Metab $\mathbf{8 8}, 3177-3183$.

261. Wren AM, Small CJ, Abbott CR, et al. (2001) Ghrelin causes hyperphagia and obesity in rats. Diabetes 50, 2540-2547.

262. Chen HY, Trumbauer ME, Chen AS, et al. (2004) Orexigenic action of peripheral ghrelin is mediated by neuropeptide $\mathrm{Y}$ and Agouti-related protein. Endocrinology 145, 2607-2612.

263. López M, Lage R, Saha AK, et al. (2008) Hypothalamic fatty acid metabolism mediates the orexigenic action of ghrelin. Cell Metab 7, 389-399.

264. Wortley KE, Del Rincon JP, Murray JD, et al. (2005) Absence of ghrelin protects against early-onset obesity. J Clin Invest 115, 3573-3578.

265. Zigman JM, Nakano Y, Coppari R, et al. (2005) Mice lacking ghrelin receptors resist the development of diet-induced obesity. J Clin Invest 115, 3564-3572.

266. Pfluger PT, Kirchner H, Günnel S, et al. (2008) Simultaneous deletion of ghrelin and its receptor increases motor activity and energy expenditure. Am J Physiol Gastrointest Liver Physiol 294, G610-G618.

267. Nagaya N, Moriya J, Yasumura Y, et al. (2004) Effects of ghrelin administration on left ventricular function, exercise capacity, and muscle wasting in patients with chronic heart failure. Circulation 110, 3674-3679.

268. Nagaya N, Itoh T, Murakami S, et al. (2005) Treatment of cachexia with ghrelin in patients with COPD. Chest 128, 1187-1193.

269. Drucker DJ (2006) The biology of incretin hormones. Cell Metab 3, 153-165.

270. Brown JC (1971) A gastric inhibitory polypeptide. I. The amino acid composition and the tryptic peptides. Can J Biochem 49, 255-261. 
271. Song DH \& Wolfe MM (2007) Glucose-dependent insulinotropic polypeptide and its role in obesity. Curr Opin Endocrinol Diabetes Obes 14, 46-51.

272. Roust LR, Stesin M, Go VL, et al. (1988) Role of gastric inhibitory polypeptide in postprandial hyperinsulinemia of obesity. Am J Physiol 254, E767-E774.

273. Drucker DJ (2007) The role of gut hormones in glucose homeostasis. J Clin Invest 117, 24-32.

274. Wideman RD \& Kieffer TJ (2009) Mining incretin hormone pathways for novel therapies. Trends Endocrinol Metab 20, 280-286.

275. Fehmann HC, Goke R \& Goke B (1995) Cell and molecular biology of the incretin hormones glucagon-like peptide-I and glucose-dependent insulin releasing polypeptide. Endocr Rev 16, 390-410

276. Wasada T, McCorkle K, Harris V, et al. (1981) Effect of gastric inhibitory polypeptide on plasma levels of chylomicron triglycerides in dogs. J Clin Invest $\mathbf{6 8}$, 1106-1107.

277. Song DH, Getty-Kaushik L, Tseng E, et al. (2007) Glucosedependent insulinotropic polypeptide enhances adipocyte development and glucose uptake in part through Akt activation. Gastroenterology 133, 1796-1805.

278. Althage MC, Ford EL, Wang S, et al. (2008) Targeted ablation of glucose-dependent insulinotropic polypeptideproducing cells in transgenic mice reduces obesity and insulin resistance induced by a high fat diet. $J$ Biol Chem 283, 18365-18376.

279. Miyawaki K, Yamada Y, Ban N, et al. (2002) Inhibition of gastric inhibitory polypeptide signaling prevents obesity. Nat Med 8, 738-742.

280. Gault VA, Irwin N, Green BD, et al. (2005) Chemical ablation of gastric inhibitory polypeptide receptor action by daily $\left(\mathrm{PrO}^{3}\right.$ )GIP administration improves glucose tolerance and ameliorates insulin resistance and abnormalities of islet structure in obesity-related diabetes. Diabetes $\mathbf{5 4}$, $2436-2446$

281. Hansotia T, Maida A, Flock G, et al. (2007) Extrapancreatic incretin receptors modulate glucose homeostasis, body weight, and energy expenditure. J Clin Invest 117, $143-152$.

282. Daousi C, Wilding JP, Aditya S, et al. (2009) Effects of peripheral administration of synthetic human glucosedependent insulinotropic peptide (GIP) on energy expenditure and subjective appetite sensations in healthy normal weight subjects and obese patients with type 2 diabetes. Clin Endocrinol 71, 195-201.

283. Irwin N \& Flatt PR (2009) Evidence for beneficial effects of compromised gastric inhibitory polypeptide action in obesity-related diabetes and possible therapeutic implications. Diabetologia 52, 1724-1731.

284. Baggio LL \& Drucker DJ (2007) Biology of incretins: GLP-1 and GIP. Gastroenterology 132, 2131-2157.

285. Kieffer TJ \& Habener JF (1999) The glucagon-like peptides. Endocr Rev 20, 876-913.

286. Drucker DJ (2005) Biologic actions and therapeutic potential of the proglucagon-derived peptides. Nat Clin Pract Endocr Metab 1, 22-31.

287. Nauck MA, Vardarli I, Deacon CF, et al. (2011) Secretion of glucagon-like peptide-1 (GLP-1) in type 2 diabetes: what is up, what is down? Diabetologia 54, 10-18.

288. Ranganath LR, Beety JM, Morgan LM, et al. (1996) Attenuated GLP-1 secretion in obesity: cause or consequence? Gut 38, 916-919.

289. Naslund E, Gryback P, Backman L, et al. (1998) Distal small bowel hormones: correlation with fasting antroduodenal motility and gastric emptying. Dig Dis Sci 43, 945-952.
290. Torekov SS, Madsbad S \& Holst JJ (2011) Obesity - an indication for GLP-1 treatment? Obesity pathophysiology and GLP-1 treatment potential. Obes Rev 12, 593-601.

291. Verdich C, Toubro S, Buemann B, et al. (2001) The role of postprandial releases of insulin and incretin hormones in meal-induced satiety - effect of obesity and weight reduction. Int J Obes Relat Metab Disord 25, 1206-1214.

292. Morínigo R, Moize V, Musri M, et al. (2006) Glucagon-like peptide-1, peptide YY, hunger, and satiety after gastric bypass surgery in morbidly obese subjects. J Clin Endocrinol Metab 91, 1735-1740.

293. Turton MD, O'Shea D, Gunn I, et al. (1996) A role for glucagon-like peptide- 1 in the central regulation of feeding. Nature 379, 69-72.

294. Flint A, Raben A, Astrup A, et al. (1998) Glucagon-like peptide 1 promotes satiety and suppresses energy intake in humans. J Clin Invest 101, 515-520.

295. Gutzwiller JP, Goke B, Drewe J, et al. (1999) Glucagon-like peptide-1: a potent regulator of food intake in humans. Gut 44, 81-86.

296. Naslund E, Barkeling B, King N, et al. (1999) Energy intake and appetite are suppressed by glucagon-like peptide-1 (GLP-1) in obese men. Int J Obes Relat Metab Disord 23, 304-311.

297. Flint A, Raben A, Ersboll AK, et al. (2001) The effect of physiological levels of glucagon-like peptide- 1 on appetite, gastric emptying, energy and substrate metabolism in obesity. Int J Obes Relat Metab Disord 25, 781-792.

298. Williams DL, Baskin DG \& Schwartz MW (2009) Evidence that intestinal glucagon-like peptide-1 plays a physiological role in satiety. Endocrinology 150, 1680-1687.

299. Osaka T, Endo M, Yamakawa M, et al. (2005) Energy expenditure by intravenous administration of glucagonlike peptide- 1 mediated by the lower brainstem and sympathoadrenal system. Peptides 26, 1623-1631.

300. Pannacciulli N, Bunt JC, Koska J, et al. (2006) Higher fasting plasma concentrations of glucagon-like peptide 1 are associated with higher resting energy expenditure and fat oxidation rates in humans. Am J Clin Nutr 84, 556-560.

301. Knauf C, Cani PD, Ait-Belgnaoui A, et al. (2008) Brain glucagon-like peptide 1 signaling controls the onset of high-fat diet-induced insulin resistance and reduces energy expenditure. Endocrinology 149, 4768-4777.

302. Ayala JE, Bracy DP, James FD, et al. (2010) Glucagon-like peptide-1 receptor knockout mice are protected from high-fat diet-induced insulin resistance. Endocrinology 151, 4678-4687.

303. Nogueiras R, Perez-Tilve D, Veyrat-Durebex C, et al. (2009) Direct control of peripheral lipid deposition by CNS GLP-1 receptor signaling is mediated by the sympathetic nervous system and blunted in diet-induced obesity. $J$ Neurosci 29, 5916-5925.

304. Barrera JG, Jones KR, Herman JP, et al. (2011) Hyperphagia and increased fat accumulation in two models of chronic CNS glucagon-like peptide-1 loss of function. J Neurosci 31, 3904-3913.

305. Hayes MR, De Jonghe BC \& Kanoski SE (2010) Role of the glucagon-like-peptide-1 receptor in the control of energy balance. Physiol Behav 100, 503-510.

306. Vilsboll T, Zdravkovic M, Le-Thi T, et al. (2007) Liraglutide, a long-acting human glucagon-like peptide-1 analog, given as monotherapy significantly improves glycemic control and lowers body weight without risk of hypoglycemia in patients with type 2 diabetes. Diabetes Care 30, 1608-1610.

307. Astrup A, Rossner S, Van Gaal L, et al. (2009) Effects of liraglutide in the treatment of obesity: a randomised, doubleblind, placebo-controlled study. Lancet 374, 1606-1616. 
308. Day JW, Ottaway N, Patterson JT, et al. (2009) A new glucagon and GLP-1 CO-agonist eliminates obesity in rodents. Nat Chem Biol 5, 749-757.

309. Tang Christensen M, Larsen PJ, Thulesen J, et al. (2000) The proglucagon-derived peptide, glucagon-like peptide- 2 , is a neurotransmitter involved in the regulation of food intake. Nat Med 6, 802-807.

310. Bahrami J, Longuet C, Baggio LL, et al. (2010) Glucagonlike peptide-2 receptor modulates islet adaptation to metabolic stress in the ob/ob mouse. Gastroenterology 139, $857-868$.

311. le Roux CW, Borg C, Wallis K, et al. (2010) Gut hypertrophy after gastric bypass is associated with increased glucagonlike peptide 2 and intestinal crypt cell proliferation. Ann Surg 252, 50-56.

312. Drucker DJ (2007) Dipeptidyl peptidase-4 inhibition and the treatment of type 2 diabetes: preclinical biology and mechanisms of action. Diabetes Care 30, 1335-1343.

313. Conarello SL, Li Z, Ronan J, et al. (2003) Mice lacking dipeptidyl peptidase IV are protected against obesity and insulin resistance. Proc Natl Acad Sci U S A 100, 6825-6830.

314. Tatemoto K \& Mutt V (1980) Isolation of two novel candidate hormones using a chemical method for finding naturally occurring polypeptides. Nature 285, 417-418.

315. Karra E \& Batterham RL (2010) The role of gut hormones in the regulation of body weight and energy homeostasis. $\mathrm{Mol}$ Cell Endocrinol 316, 120-128.

316. Grandt D, Schimiczek M, Beglinger C, et al. (1994) Two molecular forms of peptide YY (PYY) are abundant in human blood: characterization of a radioimmunoassay recognizing PYY 1-36 and PYY 3-36. Regul Pept 51, 151-159.

317. Kirchner H, Tong J, Tschöp MH, et al. (2010) Ghrelin and PYY in the regulation of energy balance and metabolism: lessons from mouse mutants. Am J Physiol Endocrinol Metab 298, E909-E919.

318. Zac-Varghese S, De Silva A \& Bloom SR (2011) Translational studies on PYY as a novel target in obesity. Curr Opin Pharmacol 11, 582-585.

319. Batterham RL, Cohen MA, Ellis SM, et al. (2003) Inhibition of food intake in obese subjects by peptide $\mathrm{YY}_{3-36} . N$ Engl J Med 349, 941-948.

320. Batterham RL, Cowley MA, Small CJ, et al. (2002) Gut hormone $\mathrm{PYY}_{3-36}$ physiologically inhibits food intake. Nature 418, 650-654.

321. Moran TH, Smedh U, Kinzig KP, et al. (2005) Peptide $\mathrm{YY}(3-36)$ inhibits gastric emptying and produces acute reductions in food intake in rhesus monkeys. Am J Physiol Regul Integr Comp Physiol 288, R384-R388.

322. Batterham RL, Ffytche DH, Rosenthal JM, et al. (2007) PYY modulation of cortical and hypothalamic brain areas predicts feeding behaviour in humans. Nature 450, 106-109.

323. Tschöp M, Castañeda TR, Joost HG, et al. (2004) Physiology: does gut hormone $\mathrm{PYY}_{3-36}$ decrease food intake in rodents? Nature 430, 1 p following 165; discussion $2 \mathrm{p}$ following 165.

324. Schonhoff S, Baggio L, Ratineau C, et al. (2005) Energy homeostasis and gastrointestinal endocrine differentiation do not require the anorectic hormone peptide YY. Mol Cell Biol 25, 4189-4199.

325. Wortley KE, Garcia K, Okamoto H, et al. (2007) Peptide YY regulates bone turnover in rodents. Gastroenterology $\mathbf{1 3 3}$, $1534-1543$.

326. Boey D, Lin S, Karl T, et al. (2006) Peptide YY ablation in mice leads to the development of hyperinsulinaemia and obesity. Diabetologia 49, 1360-1370.
327. Batterham RL, Heffron H, Kapoor S, et al. (2006) Critical role for peptide $\mathrm{YY}$ in protein-mediated satiation and body-weight regulation. Cell Metab 4, 223-233.

328. Sloth B, Holst JJ, Flint A, et al. (2007) Effects of PYY ${ }_{1-36}$ and $\mathrm{PYY}_{3-36}$ on appetite, energy intake, energy expenditure, glucose and fat metabolism in obese and lean subjects. Am J Physiol Endocrinol Metab 292, E1062-E1068.

329. Doucet E, Laviolette M, Imbeault P, et al. (2008) Total peptide $\mathrm{YY}$ is a correlate of postprandial energy expenditure but not of appetite or energy intake in healthy women. Metabolism 57, 1458-1464.

330. Guo Y, Ma L, Enriori PJ, et al. (2006) Physiological evidence for the involvement of peptide $\mathrm{YY}$ in the regulation of energy homeostasis in humans. Obesity 14, 1562-1570.

331. Raybould HE (2007) Mechanisms of CCK signaling from gut to brain. Curr Opin Pharmacol 7, 570-574.

332. Liddle RA, Goldfine ID, Rosen MS, et al. (1985) Cholecystokinin bioactivity in human plasma. Molecular forms, responses to feeding, and relationship to gallbladder contraction. J Clin Invest 75, 1144-1152.

333. Lo CM, Samuelson LC, Chambers JB, et al. (2008) Characterization of mice lacking the gene for cholecystokinin. Am J Physiol Regul Integr Comp Physiol 294, R803-R810.

334. Crawley JN \& Corwin RL (1994) Biological actions of cholecystokinin. Peptides 15, 731-755.

335. Kopin AS, Mathes WF, McBride EW, et al. (1999) The cholecystokinin-A receptor mediates inhibition of food intake yet is not essential for the maintenance of body weight. $J$ Clin Invest 103, 383-391.

336. Lo CM, King A, Samuelson LC, et al. (2010) Cholecystokinin knockout mice are resistant to high-fat diet-induced obesity. Gastroenterology 138, 1997-2005.

337. Gibbs J, Young RC \& Smith GP (1973) Cholycystokinin elicits satiety in rats with open gastric fistulas. Nature $\mathbf{2 4 5}$ 323-325.

338. Smith GP, Jerome C, Cushin BJ, et al. (1981) Abdominal vagotomy blocks the satiety effect of cholecystokinin in the rat. Science 213, 1036-1037.

339. Lieverse RJ, Jansen JB, Masclee AA, et al. (1995) Satiety effects of a physiological dose of cholecystokinin in humans. Gut 36, 176-179.

340. Crawley JN \& Beinfeld MC (1983) Rapid development of tolerance to the behavioural actions of cholecystokinin. Nature 302, 703-706.

341. Jordan J, Greenway FL, Leiter LA, et al. (2008) Stimulation of cholecystokinin-A receptors with GI181771X does not cause weight loss in overweight or obese patients. Clin Pharmacol Ther 83, 281-287.

342. Moran TH, Katz LF, Plata-Salaman CR, et al. (1998) Disordered food intake and obesity in rats lacking cholecystokinin A receptors. Am J Physiol 274, R618-R625.

343. Bataille D, Tatemoto K, Gespach C, et al. (1982) Isolation of glucagon-37 (bioactive enteroglucagon/oxyntomodulin) from porcine jejuno-ileum. Characterization of the peptide. FEBS Lett 146, 79-86.

344. Le Quellec A, Kervran A, Blache P, et al. (1992) Oxyntomodulin-like immunoreactivity: diurnal profile of a new potential enterogastrone. $J$ Clin Endocrinol Metab $\mathbf{7 4}$, 1405-1409.

345. Dubrasquet M, Bataille D \& Gespach C (1982) Oxyntomodulin (glucagon-37 or bioactive enteroglucagon): a potent inhibitor of pentagastrin-stimulated acid secretion in rats. Biosci Rep 2, 391-395.

346. Schjoldager B, Mortensen PE, Myhre J, et al. (1989) Oxyntomodulin from distal gut. Role in regulation of gastric and pancreatic functions. Dig Dis Sci 34, 1411-1419. 
347. Schepp W, Dehne K, Riedel T, et al. (1996) Oxyntomodulin: a cAMP-dependent stimulus of rat parietal cell function via the receptor for glucagon-like peptide-1 $(7-36) \mathrm{NH}_{2}$. Digestion 57, 398-405.

348. Baggio LL, Huang Q, Brown TJ, et al. (2004) Oxyntomodulin and glucagon-like peptide-1 differentially regulate murine food intake and energy expenditure. Gastroenterology 127, 546-558.

349. Parkinson JR, Chaudhri OB, Kuo YT, et al. (2009) Differential patterns of neuronal activation in the brainstem and hypothalamus following peripheral injection of GLP-1, oxyntomodulin and lithium chloride in mice detected by manganese-enhanced magnetic resonance imaging (MEMRI). Neuroimage 44, 1022-1031.

350. Dakin CL, Gunn I, Small CJ, et al. (2001) Oxyntomodulin inhibits food intake in the rat. Endocrinology 142, 4244-4250.

351. Dakin CL, Small CJ, Batterham RL, et al. (2004) Peripheral oxyntomodulin reduces food intake and body weight gain in rats. Endocrinology 145, 2687-2695.

352. Cohen MA, Ellis SM, Le Roux CW, et al. (2003) Oxyntomodulin suppresses appetite and reduces food intake in humans. J Clin Endocrinol Metab 88, 4696-4701.

353. Wynne K, Park AJ, Small CJ, et al. (2005) Subcutaneous oxyntomodulin reduces body weight in overweight and obese subjects: a double-blind, randomized, controlled trial. Diabetes 54, 2390-2395.

354. Dakin CL, Small CJ, Park AJ, et al. (2002) Repeated ICV administration of oxyntomodulin causes a greater reduction in body weight gain than in pair-fed rats. Am J Physiol Endocrinol Metab 283, E1173-E1177.

355. Wynne K \& Bloom SR (2006) The role of oxyntomodulin and peptide tyrosine-tyrosine (PYY) in appetite control. Nat Clin Pract Endocrinol Metab 2, 612-620.

356. Potter LR (2011) Guanylyl cyclase structure, function and regulation. Cell Signal 23, 1921-1926.

357. Seeley RJ \& Tschöp MH (2011) Uroguanylin: how the gut got another satiety hormone. J Clin Invest 121, 3384-3386.

358. Carrithers SL, Ott CE, Hill MJ, et al. (2004) Guanylin and uroguanylin induce natriuresis in mice lacking guanylyl cyclase-C receptor. Kidney Int 65, 40-53.

359. Frühbeck G (2012) Gastrointestinal hormones: uroguanylin - a new gut-derived weapon against obesity? Nat Rev Endocrinol 8, 5-6.

360. Lafontan M, Moro C, Berlan M, et al. (2008) Control of lipolysis by natriuretic peptides and cyclic GMP. Trends Endocrinol Metab 19, 130-137.

361. Beenken A \& Mohammadi M (2009) The FGF family: biology, pathophysiology and therapy. Nat Rev Drug Discov 8, 235-253.

362. Kir S, Beddow SA, Samuel VT, et al. (2011) FGF19 as a postprandial, insulin-independent activator of hepatic protein and glycogen synthesis. Science 331, 1621-1624.

363. Tomlinson E, Fu L, John L, et al. (2002) Transgenic mice expressing human fibroblast growth factor-19 display increased metabolic rate and decreased adiposity. Endocrinology 143, 1741-1747.

364. Fu L, John LM, Adams SH, et al. (2004) Fibroblast growth factor 19 increases metabolic rate and reverses dietary and leptin-deficient diabetes. Endocrinology $\mathbf{1 4 5}$ $2594-2603$

365. Wu X, Ge H, Lemon B, et al. (2010) Separating mitogenic and metabolic activities of fibroblast growth factor 19 (FGF19). Proc Natl Acad Sci U S A 107, 14158-14163.

366. Hirota K \& Fukamizu A (2010) Transcriptional regulation of energy metabolism in the liver. $J$ Recept Signal Transduct Res 30, 403-409.
367. Juul A (2003) Serum levels of insulin-like growth factor I and its binding proteins in health and disease. Growth Horm IGF Res 13, 113-170.

368. Kawai M \& Rosen CJ (2010) The IGF-I regulatory system and its impact on skeletal and energy homeostasis. J Cell Biochem 111, 14-19.

369. Baker J, Liu JP, Robertson EJ, et al. (1993) Role of insulinlike growth factors in embryonic and postnatal growth. Cell 75, 73-82.

370. Sandhu MS, Heald AH, Gibson JM, et al. (2002) Circulating concentrations of insulin-like growth factor-I and development of glucose intolerance: a prospective observational study. Lancet 359, 1740-1745.

371. Murphy LJ (2003) The role of the insulin-like growth factors and their binding proteins in glucose homeostasis. Experimental Diab Res 4, 213-224.

372. Clemmons DR (2006) Involvement of insulin-like growth factor-I in the control of glucose homeostasis. Curr Opin Pharmacol 6, 620-625.

373. Saltiel AR \& Kahn CR (2001) Insulin signalling and the regulation of glucose and lipid metabolism. Nature 414, 799-806.

374. Holzenberger M, Dupont J, Ducos B, et al. (2003) IGF-1 receptor regulates lifespan and resistance to oxidative stress in mice. Nature 421, 182-187.

375. Sanchez-Alavez M, Osborn O, Tabarean IV, et al. (2011) Insulin-like growth factor 1-mediated hyperthermia involves anterior hypothalamic insulin receptors. $J$ Biol Chem 286, 14983-14990.

376. Frystyk J, Vestbo E, Skjaerbaek C, et al. (1995) Free insulinlike growth factors in human obesity. Metabolism $\mathbf{4 4}$, 37-44.

377. Le Marchand-Brustel Y, Heydrick SJ, Jullien D, et al. (1995) Effected of insulin and insulin-like growth factor-I on glucose transport and its transporters in soleus muscle of lean and obese mice. Metabolism 44, 18-23.

378. Vickers MH, Ikenasio BA \& Breier BH (2001) IGF-I treatment reduces hyperphagia, obesity, and hypertension in metabolic disorders induced by fetal programming. Endocrinology 142, 3964-3973.

379. Foster LA, Ames NK \& Emery RS (1991) Food intake and serum insulin responses to intraventricular infusions of insulin and IGF-I. Physiol Behav 50, 745-749.

380. Lauterio TJ, Marson L, Daughaday WH, et al. (1987) Evidence for the role of insulin-like growth factor II (IGF-II) in the control of food intake. Physiol Behav 40, 755-758.

381. Firth SM \& Baxter RC (2002) Cellular actions of the insulinlike growth factor binding proteins. Endocr Rev 23, $824-854$

382. Wheatcroft SB, Kearney MT, Shah AM, et al. (2007) IGF-binding protein-2 protects against the development of obesity and insulin resistance. Diabetes 56, 285-294.

383. Hedbacker K, Birsoy K, Wysocki RW, et al. (2010) Antidiabetic effects of IGFBP2, a leptin-regulated gene. Cell Metab 11, 11-22.

384. Kharitonenkov A \& Larsen P (2011) FGF21 reloaded: challenges of a rapidly growing field. Trends Endocrinol Metab 22, 81-86.

385. Tyynismaa H, Raivio T, Hakkarainen A, et al. (2011) Liver fat but not other adiposity measures influence circulating FGF21 levels in healthy young adult twins. J Clin Endocrinol Metab 96, E351-E355.

386. Badman MK, Pissios P, Kennedy AR, et al. (2007) Hepatic fibroblast growth factor 21 is regulated by PPAR $\alpha$ and is a key mediator of hepatic lipid metabolism in ketotic states. Cell Metab 5, 426-437.

387. Galman C, Lundasen T, Kharitonenkov A, et al. (2008) The circulating metabolic regulator FGF21 is induced by 
prolonged fasting and PPAR $\alpha$ activation in man. Cell Metab 8, 169-174.

388. Kharitonenkov A, Shiyanova TL, Koester A, et al. (2005) FGF-21 as a novel metabolic regulator. J Clin Invest 115, 1627-1635.

389. Dushay J, Chui PC, Gopalakrishnan GS, et al. (2010) Increased fibroblast growth factor 21 in obesity and nonalcoholic fatty liver disease. Gastroenterology 139, 456-463.

390. Fisher FM, Chui PC, Antonellis PJ, et al. (2010) Obesity is a fibroblast growth factor 21 (FGF21)-resistant state. Diabetes 59, 2781-2789.

391. Xu J, Lloyd DJ, Hale C, et al. (2009) Fibroblast growth factor 21 reverses hepatic steatosis, increases energy expenditure, and improves insulin sensitivity in diet-induced obese mice. Diabetes 58, 250-259.

392. Sarruf DA, Thaler JP, Morton GJ, et al. (2010) Fibroblast growth factor 21 action in the brain increases energy expenditure and insulin sensitivity in obese rats. Diabetes 59, $1817-1824$.

393. Hondares E, Iglesias R, Giralt A, et al. (2011) Thermogenic activation induces FGF21 expression and release in brown adipose tissue. J Biol Chem 286, 12983-12990.

394. Hammond GL (2011) Diverse roles for sex hormone-binding globulin in reproduction. Biol Reprod 85, 431-441.

395. Svendsen OL, Hassager C \& Christiansen C (1993) Impact of regional and total body composition and hormones on resting energy expenditure in overweight postmenopausal women. Metabolism 42, 1588-1591.

396. Abate N, Haffner SM, Garg A, et al. (2002) Sex steroid hormones, upper body obesity, and insulin resistance. J Clin Endocrinol Metab 87, 4522-4527.

397. Ding EL, Song Y, Manson JE, et al. (2009) Sex hormonebinding globulin and risk of type 2 diabetes in women and men. $N$ Engl J Med 361, 1152-1163.

398. Calle EE \& Kaaks R (2004) Overweight, obesity and cancer: epidemiological evidence and proposed mechanisms. Nat Rev Cancer 4, 579-591.

399. Zurlo F, Larson K, Bogardus C, et al. (1990) Skeletal muscle metabolism is a major determinant of resting energy expenditure. J Clin Invest 86, 1423-1427.

400. van den Berg SA, van Marken Lichtenbelt W, Willems van Dijk K, et al. (2011) Skeletal muscle mitochondrial uncoupling, adaptive thermogenesis and energy expenditure. Curr Opin Clin Nutr Metab Care 14, 243-249.

401. Boström P, Wu J, Jedrychowski MP, et al. (2012) A PGC1$\alpha$-dependent myokine that drives brown-fat-like development of white fat and thermogenesis. Nature 481, 463-468.

402. Lee SJ (2004) Regulation of muscle mass by myostatin. Annu Rev Cell Dev Biol 20, 61-86.

403. Zimmers TA, Davies MV, Koniaris LG, et al. (2002) Induction of cachexia in mice by systemically administered myostatin. Science 296, 1486-1488.

404. Rebbapragada A, Benchabane H, Wrana JL, et al. (2003) Myostatin signals through a transforming growth factor $\beta$-like signaling pathway to block adipogenesis. Mol Cell Biol 23, 7230-7242.

405. McPherron AC \& Lee SJ (2002) Suppression of body fat accumulation in myostatin-deficient mice. J Clin Invest 109, 595-601.

406. Zhang C, McFarlane C, Lokireddy S, et al. (2012) Inhibition of myostatin protects against diet-induced obesity by enhancing fatty acid oxidation and promoting a brown adipose phenotype in mice. Diabetologia 55, 183-193.

407. Guo T, Jou W, Chanturiya T, et al. (2009) Myostatin inhibition in muscle, but not adipose tissue, decreases fat mass and improves insulin sensitivity. PLOS ONE 4, e4937.
408. Hittel DS, Berggren JR, Shearer J, et al. (2009) Increased secretion and expression of myostatin in skeletal muscle from extremely obese women. Diabetes 58, 30-38.

409. Sáinz N, Rodríguez A, Catalán V, et al. (2009) Leptin administration favors muscle mass accretion by decreasing FoxO3a and increasing PGC- $1 \alpha$ in ob/ob mice. PLoS ONE 4, e6808.

410. Brinkoetter M, Magkos F, Vamvini M, et al. (2011) Leptin treatment reduces body fat but does not affect lean body mass or the myostatin-follistatin-activin axis in lean hypoleptinemic women. Am J Physiol Endocrinol Metab 301, E99-E104.

411. Pan H, Ping XC, Zhu HJ, et al. (2012) Association of myostatin gene polymorphisms with obesity in Chinese north Han human subjects. Gene 494, 237-241.

412. Takahashi N, Lopez ML, Cowhig JE Jr, et al. (2005) Ren1c homozygous null mice are hypotensive and polyuric, but heterozygotes are indistinguishable from wild-type. $J \mathrm{Am}$ Soc Nephrol 16, 125-132.

413. Szczepanska-Sadowska E, Paczwa P \& Dobruch J (2003) Enhanced food and water intake in renin transgenic rats. J Physiol Pharmacol 54, 81-88.

414. Uehara S, Tsuchida M, Kanno T, et al. (2003) Late-onset obesity in mice transgenic for the human renin gene. Int $J$ Mol Med 11, 723-727.

415. Gratze P, Boschmann M, Dechend R, et al. (2009) Energy metabolism in human renin-gene transgenic rats: does renin contribute to obesity? Hypertension 53, 516-523.

416. Kishimoto I, Tokudome T, Nakao K, et al. (2011) Natriuretic peptide system: an overview of studies using genetically engineered animal models. FEBS J 278, 1830-1841.

417. Beleigoli AM, Diniz MF \& Ribeiro AL (2009) Natriuretic peptides: linking heart and adipose tissue in obesity and related conditions - a systematic review. Obes Rev 10, 617-626.

418. Pandey KN (2011) The functional genomics of guanylyl cyclase/natriuretic peptide receptor-A: perspectives and paradigms. FEBS J 278, 1792-1807.

419. Kuhn M (2003) Structure, regulation, and function of mammalian membrane guanylyl cyclase receptors, with a focus on guanylyl cyclase-A. Circ Res 93, 700-709.

420. Sarzani R, Dessi-Fulgheri P, Paci VM, et al. (1996) Expression of natriuretic peptide receptors in human adipose and other tissues. J Endocrinol Invest 19, 581-585.

421. Engeli S \& Sharma AM (2001) The renin-angiotensin system and natriuretic peptides in obesity-associated hypertension. J Mol Med 70, 21-29.

422. Gómez-Ambrosi J, Catalán V, Diez-Caballero A, et al. (2004) Gene expression profile of omental adipose tissue in human obesity. FASEB J 18, 215-217.

423. Moro C \& Smith SR (2009) Natriuretic peptides: new players in energy homeostasis. Diabetes 58, 2726-2728.

424. Birkenfeld AL, Boschmann M, Moro C, et al. (2005) Lipid mobilization with physiological atrial natriuretic peptide concentrations in humans. J Clin Endocrinol Metab 90, 3622-3628.

425. Sarzani R, Marcucci P, Salvi F, et al. (2008) Angiotensin II stimulates and atrial natriuretic peptide inhibits human visceral adipocyte growth. Int J Obes 32, 259-267.

426. Wang TJ, Larson MG, Levy D, et al. (2004) Impact of obesity on plasma natriuretic peptide levels. Circulation 109, 594-600.

427. Inuzuka M, Tamura N, Yamada N, et al. (2010) C-type natriuretic peptide as a new regulator of food intake and energy expenditure. Endocrinology 151, 3633-3642.

428. Miyashita K, Itoh H, Tsujimoto H, et al. (2009) Natriuretic peptides/cGMP/cGMP-dependent protein kinase cascades promote muscle mitochondrial biogenesis and prevent obesity. Diabetes 58, 2880-2892. 
429. Birkenfeld AL, Budziarek P, Boschmann M, et al. (2008) Atrial natriuretic peptide induces postprandial lipid oxidation in humans. Diabetes 57, 3199-3204.

430. Kim B (2008) Thyroid hormone as a determinant of energy expenditure and the basal metabolic rate. Thyroid $\mathbf{1 8}$, 141-144.

431. Baxter JD \& Webb P (2009) Thyroid hormone mimetics: potential applications in atherosclerosis, obesity and type 2 diabetes. Nat Rev Drug Discov 8, 308-320.

432. Yen PM (2001) Physiological and molecular basis of thyroid hormone action. Physiol Rev 81, 1097-1142.

433. Zhang J \& Lazar MA (2000) The mechanism of action of thyroid hormones. Annu Rev Physiol 62, 439-466.

434. Reinehr T (2010) Obesity and thyroid function. Mol Cell Endocrinol 316, 165-171.

435. Silva JE (2003) The thermogenic effect of thyroid hormone and its clinical implications. Ann Intern Med 139, 205-213.

436. Alkemade A (2010) Central and peripheral effects of thyroid hormone signalling in the control of energy metabolism. $J$ Neuroendocrinol 22, 56-63.

437. Barros RP \& Gustafsson JA (2011) Estrogen receptors and the metabolic network. Cell Metab 14, 289-299.

438. Park CJ, Zhao Z, Glidewell-Kenney C, et al. (2011) Genetic rescue of nonclassical ER $\alpha$ signaling normalizes energy balance in obese Er $\alpha$-null mutant mice. J Clin Invest 121, 604-612.

439. Foryst-Ludwig A, Clemenz M, Hohmann S, et al. (2008) Metabolic actions of estrogen receptor beta (ER $\beta)$ are mediated by a negative cross-talk with PPAR $\gamma$. PLoS Genet 4, e1000108.

440. Dillo WS (2007) Appetite regulation: an overview. Thyroid 17, 433-445.

441. Ishii S, Kamegai J, Tamura H, et al. (2008) Triiodothyronine (T3) stimulates food intake via enhanced hypothalamic AMP-activated kinase activity. Regul Pept 151, 164-169.

442. López M, Varela L, Vázquez MJ, et al. (2010) Hypothalamic AMPK and fatty acid metabolism mediate thyroid regulation of energy balance. Nat Med 16, 1001-1008.

443. Kaptein EM, Beale E \& Chan LS (2009) Thyroid hormone therapy for obesity and nonthyroidal illnesses: a systematic review. J Clin Endocrinol Metab 94, 3663-3675.

444. Zhao LJ, Liu YJ, Liu PY, et al. (2007) Relationship of obesity with osteoporosis. J Clin Endocrinol Metab 92, 1640-1646.

445. Galusca B, Zouch M, Germain N, et al. (2008) Constitutional thinness: unusual human phenotype of low bone quality. J Clin Endocrinol Metab 93, 110-117.

446. Clemens TL \& Karsenty G (2011) The osteoblast: an insulin target cell controlling glucose homeostasis. J Bone Miner Res 26, 677-680.

447. Scatena M, Liaw L \& Giachelli CM (2007) Osteopontin. A multifunctional molecule regulating chronic inflammation and vascular disease. Arterioscler Thromb Vasc Biol 27, $2302-2309$

448. Reinholt FP, Hultenby K, Oldberg A, et al. (1990) Osteopontin - a possible anchor of osteoclasts to bone. Proc Natl Acad Sci U S A 87, 4473-4475.

449. Gómez-Ambrosi J, Catalán V, Ramírez B, et al. (2007) Plasma osteopontin levels and expression in adipose tissue are increased in obesity. J Clin Endocrinol Metab 92, 3719-3727.

450. Nomiyama T, Perez-Tilve D, Ogawa D, et al. (2007) Osteopontin mediates obesity-induced adipose tissue macrophage infiltration and insulin resistance in mice. $J$ Clin Invest 117, 2877-2888.

451. Kiefer FW, Zeyda M, Todoric J, et al. (2008) Osteopontin expression in human and murine obesity: extensive local upregulation in adipose tissue but minimal systemic alterations. Endocrinology 149, 1350-1357.
452. Catalán V, Gómez-Ambrosi J, Rodríguez A, et al. (2009) Increased adipose tissue expression of lipocalin-2 in obesity is related to inflammation and matrix metalloproteinase2 and -9 activity in humans. J Mol Med 87, 803-813.

453. Chapman J, Miles PD, Ofrecio JM, et al. (2010) Osteopontin is required for the early onset of high fat diet-induced insulin resistance in mice. PLOS ONE 5, e13959.

454. Pietiläinen KH, Naukkarinen J, Rissanen A, et al. (2008) Global transcript profiles of fat in monozygotic twins discordant for BMI: pathways behind acquired obesity. PLOS Med 5, e51.

455. Hurtado Del Pozo C, Calvo RM, Vesperinas-Garcia G, et al. (2010) IPO8 and FBXL10: new reference genes for gene expression studies in human adipose tissue. Obesity 18, 897-903.

456. Kiefer FW, Zeyda M, Gollinger K, et al. (2010) Neutralization of osteopontin inhibits obesity-induced inflammation and insulin resistance. Diabetes 59, 935-946.

457. Bertola A, Deveaux V, Bonnafous S, et al. (2009) Elevated expression of osteopontin may be related to adipose tissue macrophage accumulation and liver steatosis in morbid obesity. Diabetes 58, 125-133.

458. Syn WK, Choi SS, Liaskou E, et al. (2011) Osteopontin is induced by hedgehog pathway activation and promotes fibrosis progression in nonalcoholic steatohepatitis. Нераtology 53, 106-115.

459. Catalán V, Gómez-Ambrosi J, Rodríguez A, et al. (2011) Up-regulation of the novel proinflammatory adipokines lipocalin-2, chitinase-3 like-1 and osteopontin as well as angiogenic-related factors in visceral adipose tissue of patients with colon cancer. J Nutr Biochem 22, 634-641.

460. Calvo MS, Eyre DR \& Gundberg CM (1996) Molecular basis and clinical application of biological markers of bone turnover. Endocr Rev 17, 333-368.

461. Kanazawa I, Yamaguchi T, Yamamoto M, et al. (2009) Serum osteocalcin level is associated with glucose metabolism and atherosclerosis parameters in type 2 diabetes mellitus. J Clin Endocrinol Metab 94, 45-49.

462. Fernández-Real JM \& Ricart W (2011) Osteocalcin: a new link between bone and energy metabolism. Some evolutionary clues. Curr Opin Clin Nutr Metab Care 14, 360-366.

463. Ducy P (2011) The role of osteocalcin in the endocrine cross-talk between bone remodelling and energy metabolism. Diabetologia 54, 1291-1297.

464. Lee NK, Sowa H, Hinoi E, et al. (2007) Endocrine regulation of energy metabolism by the skeleton. Cell 130, 456-469.

465. Martin TJ (2007) A skeleton key to metabolism. Nat Med 13, 1021-1023.

466. Ferron M, Hinoi E, Karsenty G, et al. (2008) Osteocalcin differentially regulates $\beta$ cell and adipocyte gene expression and affects the development of metabolic diseases in wild-type mice. Proc Natl Acad Sci U S A 105, 5266-5270.

467. Ferron M, McKee MD, Levine RL, et al. (2012) Intermittent injections of osteocalcin improve glucose metabolism and prevent type 2 diabetes in mice. Bone 50, 568-575.

468. Kanazawa I, Yamaguchi T, Tada Y, et al. (2011) Serum osteocalcin level is positively associated with insulin sensitivity and secretion in patients with type 2 diabetes. Bone 48, 720-725.

469. Fernández-Real JM, Izquierdo M, Ortega F, et al. (2009) The relationship of serum osteocalcin concentration to insulin secretion, sensitivity, and disposal with hypocaloric diet and resistance training. J Clin Endocrinol Metab 94, 237-245.

470. Yoshikawa Y, Kode A, Xu L, et al. (2011) Genetic evidence points to an osteocalcin-independent influence of osteoblasts on energy metabolism. J Bone Miner Res 26, 2012-2025. 